\title{
Eliminating Trade Remedies from the WTO: Lessons from Regional Trade Agreements
}

Tania Voon

Georgetown University Law Center, tv23@law.georgetown.edu

This paper can be downloaded free of charge from:

https://scholarship.law.georgetown.edu/facpub/226

Int'I \& Comp. L.Q. (forthcoming, 2010)

This open-access article is brought to you by the Georgetown Law Library. Posted with permission of the author. Follow this and additional works at: https://scholarship.law.georgetown.edu/facpub

Part of the International Trade Law Commons 


\title{
GEORGETOWN LAW Faculty Publications
}

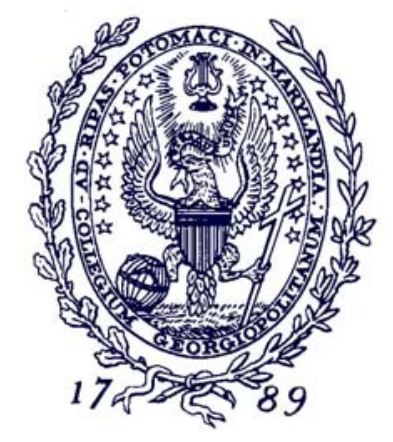

Georgetown Business, Economics \& Regulatory Law Research Paper No. 1504030 November 2009

\section{Eliminating Trade Remedies from the WTO: Lessons from Regional Trade Agreements}

Int'l \& Comp. L.Q. (forthcoming, 2010)

\author{
Tania Voon \\ Visiting Associate Professor of Law \\ Georgetown University Law Center \\ tv23@law.georgetown.edu
}

This paper can be downloaded without charge from: Scholarly Commons: http://scholarship.law.georgetown.edu/facpub/226/

SSRN: http: / / ssrn.com/abstract $=1504030$

Posted with permission of the author 


\title{
ELIMINATING TRADE REMEDIES FROM THE WTO: LESSONS FROM REGIONAL TRADE AGREEMENTS
}

\author{
TANIA VOON*
}

RTAS AND TRADE REMEdies As EXCEPTIONS to CORE WTO DiscipLINES .................. 4

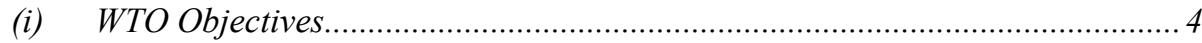

(ii) RTAs as an Exception to MFN Treatment ..................................................... 4

(iii) Trade Remedies as Established Exceptions to Various WTO Rules....................5

B The TRouble With TRAde Remedies, AND IDEAS FOR REFORM .................................. 6

(i) Anti-Dumping and Countervailing Measures.................................................. 6

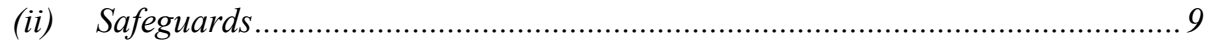

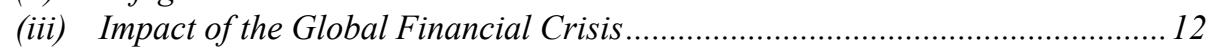

III RTAS AS MODELS FOR REDUCING TRADE REMEDIES? ……....................................13

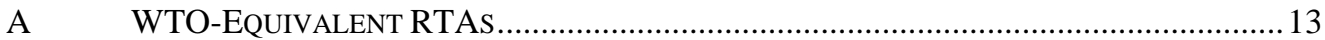

(i) Category 1: No Changes to WTO Rules.......................................................... 13

(ii) Category 2: Introduction of Bilateral Safeguards........................................ 14

(iii) Category 3: Procedural Modifications and Bilateral Safeguards................... 15

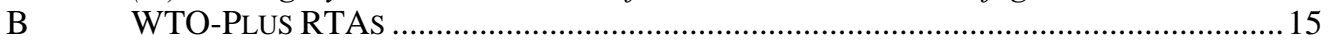

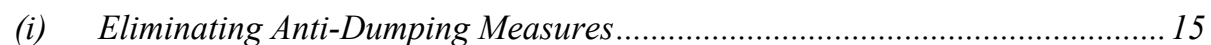

(ii) Eliminating Countervailing Measures..................................................... 18

(iii) Eliminating Safeguards ....................................................................... 19

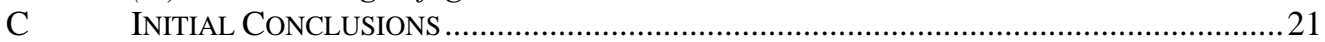

IV LEGALITY OF RTAS RESTRICTING TRADE REMEDIES.......................................22

A Legality of INTER SE Modifications to the WTO AgREEMENTS ..........................22

(i) Applicability of Article 41(1) of the VCLT in the WTO..................................2. 23

(ii) Effect of Articles X and IX of the Marrakesh Agreement ...............................25

(iii) Implications of Article 41(1) of the VCLT for RTAs.......................................26

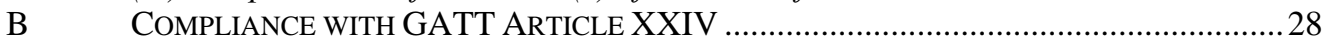

(i) Article XXIV:8 - Lowering Intra-RTA Barriers …………………...............2. 28

(ii) Article XXIV:5 - Restricting Impact on Non-RTA Members...........................29

(iii) Eliminating Safeguards ................................................................................. 30

(iv) Eliminating Anti-Dumping and Countervailing Measures...............................34

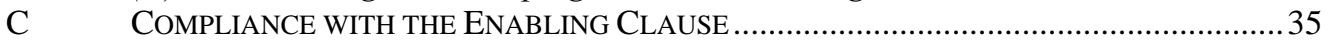

VI ANNEX 1: WTO-EQUIVALENT RTAS ..........................................................................37

\footnotetext{
* $\quad$ PhD (Cambridge); LLM (Harvard); Grad Dip Intl L, LLB (Hons), BSc (Melbourne); AMusA; Associate Professor, Melbourne Law School, University of Melbourne; Former Legal Officer, Appellate Body Secretariat, World Trade Organization; Fellow, Tim Fischer Centre for Global Trade \& Finance, Bond University; Barrister and Solicitor, Supreme Court of Victoria and High Court of Australia. Email< <ania.voon@unimelb.edu.au>. This research project was generously supported by an Early Career Researcher Grant from the University of Melbourne and by resources provided by Georgetown University Law Center. Thanks also to Laura Bellamy, Erica Leaney, Jessica Rae, Bolívar Manuel Sánchez Miranda, and Elizabeth Sheargold, for their valuable research assistance. Finally, I am grateful to Louise Hingee, Sergio López-Ayllón, Iain Sandford, Debra Steger, Joel Trachtman and Elizabeth Young for helpful discussions and feedback, as well as the organisers of and participants in the WTO Appellate Body Speaker Series in Geneva on 15 July 2009 and the Harvard-Stanford Junior Faculty Forum in Cambridge, Massachusetts on 6 November 2009. All opinions expressed here, and any errors, are mine.
} 
[Abstract: As the global financial crisis threatens to manifest in enhanced protectionism, the economic irrationality of dumping, countervailing, and global safeguard measures (so-called 'trade remedies') should be of increased concern to the Members of the World Trade Organization ('WTO'). Long tolerated under the WTO agreements and perhaps a necessary evil to facilitate multilateral trade liberalisation, elimination of trade remedies is far from the agenda of WTO negotiators. However, a small number of regional trade agreements offer a model for reducing the use of trade remedies among WTO Members in the longer term, consistent with WTO rules and broader public international law.]

\section{INTRODUCTION}

Current difficulties in the Doha Round of multilateral negotiations at the World Trade Organization ('WTO') are reflected in the proliferation of bilateral and plurilateral trade agreements according preferential treatment to individual trade partners (generally referred to as preferential, regional or free trade agreements ('RTAs')), ${ }^{1}$ as well as the continued use of so-called 'trade remedies' (anti-dumping, countervailing, and safeguard measures ostensibly intended to counter 'unfair' trade or unexpected increases in imports) as a tool to protect local industry. Both of these developments threaten to undermine the underlying objectives of the WTO, which include enhancing global welfare through trade liberalisation while taking into account the particular needs and goals of each WTO Member. This paper reflects on the widespread use of RTAs and trade remedies in order to provide lessons for the benefit of all WTO Members. In particular, it explores RTAs as positive models to reduce or eliminate the use of trade remedies among WTO Members, providing a concrete case study of the potential for 'multilateralizing regionalism'.

Reducing reliance on trade remedies would diminish market distortions and enable fairer competition among producers across the world, bringing the WTO closer to its theoretical foundations (encouraging Members to specialise in areas in which they have a comparative advantage) and hence closer to its broader welfare objectives. This goal is all the more critical in the current global financial climate, when WTO Members worldwide appear particularly tempted to use trade remedies to protect their industries. ${ }^{3}$ The continued and widespread use of trade remedies by WTO Members has led some to conclude that ' $[\mathrm{t}]$ rade remedies appear to be permanent fixtures in

1 In this paper, the term 'RTA' encompasses both 'free-trade areas' and 'customs unions' as defined in Article XXIV:8 of the WTO's General Agreement on Tariffs and Trade 1994, as discussed further in section IVB(i) below. I use this term for convenience, recognising that many 'RTAs' are not in fact between geographically proximate territories.

2 This term is taken from Richard Baldwin and Patrick Low (eds), Multilateralizing Regionalism (Cambridge: Cambridge University Press, 2009).

See, eg, WTO Press Release 556, 'WTO Secretariat reports increase in new anti-dumping investigations' (7 May 2009); International Centre for Trade and Sustainable Development, 'WTO Warns of “Significant Slippage” toward Protectionism' (2009) 13(12) Bridges Weekly Trade News Digest 4; WTO, World Trade Report 2009 (WTO: Geneva, 2009) 19. 
international trade agreements'. ${ }^{4}$ It is true that a wide range of developed and developing countries (well beyond the group of traditional users) are now heavily reliant on trade remedies, rendering impossible wholesale reform in the near future. However, this should not prevent thoughtful, steady progress towards the longer-term goal of reducing the use of trade remedies among WTO Members, in order to begin to bridge the gap between economic rationality and political reality regarding trade remedies in the WTO. It may well be too soon to propose the wholesale elimination of anti-dumping measures or any other form of trade remedy in the WTO, but I do not believe it is too late.

Part II of this paper describes in more detail the tension that exists between WTO obligations and objectives on the one hand and RTAs and trade remedies on the other, focusing on the theoretical and practical problems created by trade remedies for the multilateral trading system. In doing so, it introduces the exceptions for trade remedies contained in the WTO's General Agreement on Tariffs and Trade 1994 ('GATT 1994'), ${ }^{5}$ Agreement on Implementation of Article VI of the General Agreement on Tariffs and Trade 1994 ('Anti-Dumping Agreement'), ${ }^{6}$ Agreement on Subsidies and Countervailing Measures ('SCM Agreement'), ${ }^{7}$ and Agreement on Safeguards ('Safeguards Agreement'). ${ }^{8}$ It also outlines possible reforms to improve the current system in the longer term. Part III reviews more than 150 RTAs to determine the extent to which their provisions restrict or eliminate trade remedies among RTA partners, the corresponding implications for international trade, and the conditions that facilitated this result. Part IV considers whether Article 41(1) of the Vienna Convention on the Law of Treaties ('VCLT'), ${ }^{9}$ Article XXIV of the GATT 1994, or other WTO provisions allow or require the elimination of trade remedies in RTAs, or whether, conversely, they pose an obstacle to this approach and therefore preclude the use of RTAs as a step towards reducing the use of trade remedies among WTO Members more generally.

The paper concludes that a small number of RTAs do provide realistic models for ultimately reducing or eliminating trade remedies across the WTO Membership. Eventually, WTO Members could instead respond to predatory dumping with competition laws, to illegal subsidies with WTO dispute settlement, and to import surges with safeguards pursuant to a reformed safeguard regime. In the shorter term, WTO provisions do not prevent RTA partners from eliminating trade remedies amongst themselves.

\footnotetext{
4 Robert Teh, Thomas Prusa and Michele Budetta, 'Trade Remedy Provisions in Regional Trade Agreements' in Antoni Estevadeordal, Kati Suominen and Robert Teh (eds), Regional Rules in the Global Trading System (New York: Cambridge University Press, 2009) 166, 245. But see Robert McGee and Yeomin Yoon, 'Anti-dumping rules should be consigned to the history books', Financial Times (3 July 2009).

LT/UR/A-1A/1/GATT/1 (signed 15 April 1994, entered into force 1 January 1995).

LT/UR/A-1A/3 (signed 15 April 1994, entered into force 1 January 1995).

LT/UR/A-1A/9 (signed 15 April 1994, entered into force 1 January 1995).

LT/UR/A-1A/8 (signed 15 April 1994, entered into force 1 January 1995).

1155 UNTS 331 (adopted 22 May 1969).
} 


\section{The Problem, AND LONG-TERM SOLUTIONS}

\section{A RTAs and Trade Remedies as Exceptions to Core WTO Disciplines}

The WTO seeks to achieve objectives such as 'raising standards of living' and 'ensuring full employment' by 'entering into reciprocal and mutually advantageous arrangements directed to the substantial reduction of tariffs and other barriers to trade and to the elimination of discriminatory treatment in international trade relations' ${ }^{10}$ Subject to compliance with stringent conditions, WTO rules permit both RTAs and trade remedies, even though they would otherwise violate core obligations or 'disciplines' imposed on WTO Members in order to liberalise trade and thereby improve national and global welfare. Thus, trade remedies are 'trade protection that you can get away with under the anti-dumping agreement', ${ }^{11}$ the SCM Agreement, and the Safeguards Agreement, and RTAs reflect 'discriminatory trade policy that you can get away with under Article XXIV'12 of the GATT 1994.

RTAs represent a major exception to the key pillar of non-discrimination in the WTO: the obligation to provide most-favoured nation ('MFN') treatment to each WTO Member. The MFN rule in the context of trade in goods means that a Member must provide any benefit it accords to the products of one country (whether or not that country is a WTO Member) to the products of all WTO Members (GATT Article I:1). Members' overzealous entry into multiple RTAs in recent years has seriously damaged the MFN rule and the principle of non-discrimination. ${ }^{13}$ One factor that has allowed this explosion of RTAs has been uncertainty surrounding the WTO exception for RTAs, ${ }^{14}$ which arises from ambiguous drafting ${ }^{15}$ and a dearth of relevant and helpful WTO jurisprudence and scholarly investigation. MFN treatment has become the exception rather than the rule, with almost all Members providing preferential treatment to specific Members pursuant to a range of RTAs. This distorts international trade, prevents producers from competing on a level playing field, and negates the benefits of the MFN rule (particularly for smaller and weaker Members). However, RTAs may have some trade-liberalising effects and thus provide building blocks on

\footnotetext{
10 Marrakesh Agreement Establishing the World Trade Organization, LT/UR/A/2 (signed 15 April 1994, entered into force 1 January 1995) ('Marrakesh Agreement') preamble.

11 Theresa Carpenter, 'A historical perspective on regionalism' in Richard Baldwin and Patrick Low (eds), Multilateralizing Regionalism (Cambridge: Cambridge University Press, 2009) 13, 14 (citing Michael Finger, Antidumping: How It Works and Who Gets Hurt (Ann Arbor: University of Michigan Press, 1993).

12 Theresa Carpenter, 'A historical perspective on regionalism' in Richard Baldwin and Patrick Low (eds), Multilateralizing Regionalism (Cambridge: Cambridge University Press, 2009) 13, 14.

13 See, eg, WTO Consultative Board, The Future of the WTO: Addressing Institutional Challenges in the New Millennium (Geneva: WTO, 2004) ch II. See also Jagdish Bhagwati and Arvind Panagariya, 'Preferential Trading Areas and Multilateralism—Strangers, Friends, or Foes?' in Jagdish Bhagwati and Arvind Panagariya (eds), The Economics of Preferential Trade Agreements (Washington, DC: The AEI Press, 1996) 1.

14 GATT 1994, Article XXIV:5.

15 Particularly in GATT 1994 Article XXIV:8.
} 
the path to multilateral trade liberalisation. ${ }^{16}$ For this reason, Article XXIV:5 provides an exception for RTAs, as discussed further below. ${ }^{17}$

This paper seeks to elucidate WTO law on RTAs and to harness the prevalence of RTAs to turn them from a negative to a positive force with respect to trade remedies. In particular, the existence of RTA partners trading amongst themselves without resorting to trade remedies may provide a valuable basis for learning how to reduce trade remedies in the WTO.

Trade remedies represent a significant incursion into core WTO disciplines created to liberalise trade. These measures are permitted (but not required) by WTO rules. However, in the absence of the existing exceptions in GATT $1994^{18}$ (as agreed by the WTO Members):

- anti-dumping and countervailing measures (which generally take the form of higher tariffs/customs duties on imports of specific products from particular countries) would violate the MFN rule, ${ }^{19}$ because the imports on which they are imposed receive less favourable treatment than imports from other countries;

- safeguards (which typically take the form of higher tariffs or quantitative restrictions such as import quotas on imports of given products) could violate the general WTO prohibition on quantitative restrictions; ${ }^{20}$ and

- all three trade remedies could violate individual Members' schedules of tariff bindings (ceilings above which the relevant Member has agreed not to impose tariffs on specific products).

In concluding the GATT 1947, negotiators incorporated these exceptions for trade remedies in part because some countries (the United States ('US') in particular) would not otherwise have agreed to other aspects of liberalisation mandated by that agreement. $^{21}$ The GATT contracting parties maintained and clarified these exceptions in the GATT 1994 and the related trade remedy agreements upon the creation of the WTO. In this sense, trade remedies are not 'self-balancing': '[t]rade-offs between

16 For discussion of the economic impact of RTAs, see Viet Do and William Watson, 'Economic Analysis of Regional Trade Agreements' in Lorand Bartels and Federico Ortino (eds), Regional Trade Agreements and the WTO Legal System (New York: Oxford University Press, 2006) 7-22. See also David Gantz, Regional Trade Agreements: Law, Policy and Practice (Durham, North Carolina: Carolina Academic Press, 2009) 17-25.

17 See sections IVA and IVB.

18 See GATT 1994, Articles II:2(b), VI:2, VI:3, XIX:1(a).

19 On the relationship between safeguards and the MFN rule, see below section IVB(iii).

20 GATT 1994, Article XI:1.

21 See Michael Trebilcock and Robert Howse, The Regulation of International Trade (New York: Routledge, $3^{\text {rd }}$ ed, 2005) 312-313 (citing Kenneth Dam, The GATT: Law and International Economic Organization (Chicago: University of Chicago Press, 1970) 99, 106); WTO, World Trade Report 2009 (WTO: Geneva, 2009) 26-30, 39. See also the references to Sykes, below nn 27, 32. 
remedies reform and concessions in other areas seem to be necessary' ${ }^{22}$ In examining trade remedies in the WTO and RTAs, one must therefore be aware of the significance of trade remedies in facilitating liberalisation more generally.

\section{B The Trouble with Trade Remedies, and Ideas for Reform}

Most economists agree that trade remedies (or at least anti-dumping and countervailing measures) are almost invariably inefficient. They disadvantage not only producers and exporters of the products on which they are imposed but also importers, consumers, and industrial users of those products in the countries imposing them. ${ }^{23}$ These harmful effects have led to calls to remove or replace trade remedies, for example by replacing anti-dumping measures with competition disciplines. ${ }^{24}$ In the following paragraphs, I provide a more detailed description of the nature of trade remedies, as defined for the purpose of this paper, and their place in the WTO agreements in order to demonstrate their economic and political significance. At the outset, it is worth noting that this paper concerns anti-dumping, countervailing and safeguard measures in the context of trade in goods rather than services. ${ }^{25}$

\section{(i) Anti-Dumping and Countervailing Measures}

Pursuant to GATT Article VI and the Anti-Dumping Agreement, a WTO Member may impose anti-dumping measures on imports of a given product from another Member where its investigating authorities have found that the imported product is being 'dumped' and thereby causing injury to the domestic industry that produces the like product. Products are essentially dumped when they are sold at a lower price in the importing country than in the exporting country (after making adjustments for transport costs etc). ${ }^{26}$

From the perspective of the importing country at least, anti-dumping measures are economically irrational because they are usually passed on to the consumer by increasing the price of the good. The higher prices paid by the consumer (or industrial user) in the importing country outweigh the benefits gained by the protection afforded to the competing domestic industry. Moreover, several legitimate commercial reasons exist for dumping, so dumping is not necessarily an 'unfair' practice for which foreign producers or exporters should be penalised. Anti-dumping measures may therefore

\footnotetext{
22 Richard Baldwin, Simon Evenett and Patrick Low, 'Beyond tariffs: multilateralizing non-tariff RTA commitments' in Richard Baldwin and Patrick Low (eds), Multilateralizing Regionalism (Cambridge: Cambridge University Press, 2009) 79, 137.

${ }_{23}$ See, eg, Michael Finger, Francis Ng, and Sonam Wangchuk, Antidumping as Safeguard Policy, World Bank Policy Research Working Paper 2730 (Washington DC: World Bank, 2001).

24 See, eg, Peter Lloyd, 'Anti-Dumping and Competition Law' in Patrick Macrory, Arthur Appleton and Michael Plummer (eds), The World Trade Organization: Legal, Economic and Political Analysis (New York: Springer, 2005) vol II, 67-82; Senator Joe Ludwig, A Fair Go for Australian Industry: Labor's Policy Discussion Paper on Australia's Anti-Dumping Administration (2006); Martyn Taylor, International Competition Law: A New Dimension for the WTO? (Cambridge: Cambridge University Press, 2006) ch 9. Cf Sungjoon Cho, 'Anticompetitive Trade Remedies: How Antidumping Measures Obstruct Market Competition’ (2009) 87 North Carolina Law Review 357.

25 See below nn 26, 30 and 41.

26 GATT 1994, Articles VI:1, VI:2; Anti-Dumping Agreement, Articles 1, 2.1, 3.1, 3.5. Antidumping measures apply only to trade in goods. The WTO's General Agreement on Trade in Services LT/UR/A-1B/S/1 (signed 15 April 1994, entered into force 1 January 1995) ('GATS') does not mention dumping or anti-dumping measures.
} 
hinder legitimate foreign competition, to the detriment of the consumer and the development of the domestic industry, even if the importer or exporter absorbs them rather than adding them to the price of the product. Although anti-dumping measures may be an economically rational response to 'predatory dumping' (designed to wipe out the competition before raising the price above a competitive level), this kind of dumping is extremely unlikely to occur in practice. In any case, the Anti-Dumping Agreement does not target predatory dumping by requiring domestic investigating authorities to examine intent before imposing anti-dumping measures. ${ }^{27}$

In contrast, as discussed fully elsewhere, ${ }^{28}$ competition disciplines in place of antidumping measures could better focus the response to dumping on commercially illegitimate behaviour. However, the question of interaction between competition policy and international trade is currently outside the negotiating mandate of WTO Members, and harmonised competition laws across the WTO Membership are a long way off. ${ }^{29}$ Moreover, a wide range of developed and developing countries are now heavily reliant on anti-dumping measures: this group has expanded significantly beyond the traditional users. Accordingly, this model for reform does not provide a feasible solution for the medium to short term.

Pursuant to GATT Article VI and the SCM Agreement, a WTO Member may impose countervailing measures on imports of a given product where its investigating authorities have determined that it is being subsidised by another Member and thereby causing injury to the domestic industry that produces the like product. ${ }^{30}$ Countervailing measures will only ever be useful where the imposing Member is concerned about the impact of subsidies in its own market (as opposed to the impact in the market of the subsidising Member or in a third country), since countervailing measures are typically imposed in the form of import tariffs in the domestic market.

Like anti-dumping measures, countervailing measures are almost always welfarereducing in the importing country even though they may protect the competing

27 See Petros Mavroidis, Patrick Messerlin and Jasper Wauters, The Law and Economics of Contingent Protection in the WTO (Cheltenham: Edward Elgar, 2008) 7-18; Alan Sykes, 'Comparative Advantage and the Normative Economics of International Trade Policy' (1998) 1(1) Journal of International Economic Law 49, 80-81; Alan Sykes, 'International Trade: Trade Remedies' in Andrew Guzman and Alan Sykes (eds), Research Handbook in International Economic Law (Cheltenham: Edward Elgar, 2007) 62, 97-101; Michael Trebilcock and Robert Howse, The Regulation of International Trade (New York: Routledge, $3^{\text {rd }}$ ed, 2005) 250-261; Edwin Vermulst, The WTO AntiDumping Agreement: A Commentary (Oxford: Oxford University Press, 2005) n 7; WTO, World Trade Report 2009 (WTO: Geneva, 2009) xv-xvii, 65-73, 83-84. Cf Jacob Viner, Dumping: A Problem in International Trade (Chicago: University of Chicago Press, 1923, reprinted 1991 by Augustus M Kelley, Publishers) 120-122, 147; Gabrielle Marceau, Anti-Dumping and Anti-Trust Issues in Freetrade Areas (Oxford University Press: Oxford, 1994) 43.

28 See above $\mathrm{n} 24$ and corresponding text.

29 WTO General Council, Decision Adopted by the General Council on 1 August 2004, WT/L/579 (2 August 2004) [1(g)]. See also Andrew Mitchell, 'Broadening the Vision of Trade Liberalisation: International Competition Law and the WTO’ (2001) 24 World Competition: Law and Economics Review 343.

$30 \quad$ GATT 1994, Article VI:3; SCM Agreement, Articles 10, 15.1, 15.5. Countervailing measures apply only to trade in goods. Article XV of the GATS provides for further negotiations on subsidies in the services context but does not mention countervailing measures. 
domestic industry, ${ }^{31}$ because they tend to be passed on so that the consumer pays a higher price for the import. Contrary to their supposed purpose, countervailing measures are also unlikely in practice to induce a State to change its practice or policy of subsidising a particular product. ${ }^{32}$ Finally_again mirroring the Anti-Dumping Agreement-in allowing countervailing measures, Part V of the SCM Agreement does not target predatory conduct that might flow from subsidies. ${ }^{33}$ The agreement has in fact been described as 'one of the least economics-informed agreements in the WTO'. ${ }^{34}$

One difference between countervailing and anti-dumping measures (or, indeed, safeguards) is that they represent only one of two means of responding to a subsidy, because they target the conduct of a WTO Member rather than commercial actors. Although the WTO Members 'condem[n]' dumping that causes or threatens material injury to the domestic industry, ${ }^{35}$ dumping itself is not illegal under WTO rules or challengeable in the WTO dispute settlement system, at least in part because this system is restricted to resolving disputes between WTO Members, and WTO Members themselves do not engage in dumping. In contrast, subsidies involve a 'financial contribution by a government or any public body'. ${ }^{36}$ The WTO Members have agreed that certain subsidies are harmful and can therefore themselves constitute a violation of Part II (Prohibited Subsidies) or Part III (Actionable Subsidies) of the SCM Agreement. These violations can be challenged in the WTO dispute settlement system. ${ }^{37}$

Pursuing a subsidy through the multilateral route of WTO dispute settlement is generally preferable to imposing countervailing measures from an economic perspective. $^{38}$ Although some (illegal) subsidies ${ }^{39}$ could be countered with either a countervailing measure or a recommendation of the Dispute Settlement Body, ${ }^{40}$ the

31 See Gary Horlick and Debra Steger, 'Subsidies and Countervailing Duties' in Peter Morici (ed), Making Free Trade Work: The Canada-U.S. Agreement (New York: Council on Foreign Relations Press, 1990) 84, 86.

32 See Alan Sykes, 'International Trade: Trade Remedies’ in Andrew Guzman and Alan Sykes (eds), Research Handbook in International Economic Law (Cheltenham: Edward Elgar, 2007) 62, 106-109; Alan Sykes, 'Subsidies and Countervailing Measures' in Patrick Macrory, Arthur Appleton and Michael Plummer (eds), The World Trade Organization: Legal, Economic and Political Analysis (New York: Springer, 2005) vol II, 83, 84, 103-105.

33 Michael Trebilcock and Robert Howse, The Regulation of International Trade (New York: Routledge, $3^{\text {rd }}$ ed, 2005) 283.

34 Petros Mavroidis, Patrick Messerlin and Jasper Wauters, The Law and Economics of Contingent Protection in the WTO (Cheltenham: Edward Elgar, 2008) 462. Cf WTO, World Trade Report 2009 (WTO: Geneva, 2009) xvii-xviii, 88-95, 101-102.

35 GATT, Article VI:1.

36 SCM Agreement, Article 1.1(a)(1).

37 SCM Agreement, Article 30.

38 Alan Sykes, 'Subsidies and Countervailing Measures' in Patrick Macrory, Arthur Appleton and Michael Plummer (eds), The World Trade Organization: Legal, Economic and Political Analysis (New York: Springer, 2005) vol II, 83, 104-105.

39 In particular, an injurious subsidy could fall under Article 5(a) of the SCM Agreement in a WTO dispute settlement proceeding, and satisfy the requirements of Article 10 of the SCM Agreement in a countervailing duty investigation. An injurious subsidy could also be prohibited under Article 3 of the SCM Agreement or contrary to Articles 5(b) (nullification or impairment) or 5(c) (serious prejudice) of the SCM Agreement, all of which violations could be addressed in WTO dispute settlement.

40 Footnote 35 to the SCM Agreement allows for a Member to pursue both avenues at the same time (countervailing duty investigation under Part V and dispute settlement pursuant to Parts II or III), but 
former is a unilateral remedy imposed following a domestic proceeding of a WTO Member. This domestic countervailing duty investigation must be conducted in accordance with multilateral rules in the WTO (as reflected in the relevant Member's own laws and regulations), but the domestic producers still get the benefit of the countervailing measures even if the investigation is not conducted in accordance with WTO rules, at least until another Member brings a successful WTO dispute challenging the conduct of the investigation. Accordingly, in the longer term, countervailing duties may be successfully eliminated in the WTO while retaining the possibility of challenging illegal subsidies in the WTO dispute settlement system (recognising that that system itself is imperfect and that negotiations continue on its reform).

\section{(ii) Safeguards}

Pursuant to GATT Article XIX and the Safeguards Agreement, a WTO Member may impose a safeguard where its competent authorities have found in an investigation increased imports of a given product that have arisen from unforeseen developments and are injuring domestic producers of like or directly competitive products. ${ }^{41}$ Other forms of safeguards exist in the WTO but are not the subject of this paper. ${ }^{42}$ The socalled 'global' safeguards available under GATT Article XIX should also be distinguished from the 'bilateral' safeguards provided for in many RTAs, as discussed below. $^{43}$

Unlike anti-dumping and countervailing measures, global safeguards do not target allegedly unfair trading practices. Rather, they are intended to provide a 'safety valve' or 'escape clause, 44 for WTO Members whose domestic industries are facing a sudden flood of imports, and they provide a means for Members to deal with the 'adjustment costs' of trade liberalisation in an orderly manner. In theory, they may therefore play a particularly significant role in enabling WTO Members to agree to open their markets. ${ }^{45}$ Also in contrast to anti-dumping and countervailing measures, safeguards are a temporary response to an emergency and they must generally be

only one remedy may be obtained (countervailing measures, or countermeasures following a successful WTO dispute).

41 GATT 1994, Article XIX:1(a); Safeguards Agreement, Articles 1, 2.1, 4.2. Safeguards apply only to trade in goods. Article $\mathrm{X}$ of the GATS provides for further negotiations on 'the question of emergency safeguard measures' in the context of services.

42 For example, specific safeguards arise under: GATT Article XII (to address balance of payments difficulties); Article 5 of the WTO’s Agreement on Agriculture LT/UR/A-1A/2 (signed 15 April 1994, entered into force 1 January 1995); and Section 16 of the Protocol on the Accession of the People's Republic of China, annexed to WTO Ministerial Conference, Decision of 10 November 2001 on Accession of the People's Republic of China, WT/L/432 (23 November 2001) 9-10.

43 See section IIIA(ii).

44 See, eg, Kyle Bagwell and Robert Staiger, 'Enforcement, Private Political Pressure and the GATT/WTO Escape Clause' (2005) 34 Journal of Legal Studies 471; Alan Sykes, 'Protectionism as a Safeguard: A Positive Analysis of the GATT Escape Clause with Normative Speculations’ (1991) 58 University of Chicago Law Review 255.

45 Patrick Messerlin and Hilda Fridh, 'The Agreement on Safeguards Proposals for Change in the Light of the EC Steel Safeguards’ (2006) 40(4) Journal of World Trade 713, 715-716; Alan Sykes, 'The Persistent Puzzles of Safeguards: Lessons from the Steel Dispute' (2004) 7(3) Journal of International Economic Law 523, 524-525. Cf Chad Bown and Meredith Crowley, 'Safeguards' in Patrick Macrory, Arthur Appleton and Michael Plummer (eds), The World Trade Organization: Legal, Economic and Political Analysis (New York: Springer, 2005) 43, 53-54. 
imposed on an MFN basis (ie on imports of the relevant product from all countries). ${ }^{46}$ The Member imposing them must also generally provide compensation to other affected Members who have engaged in consultations on the matter, in order to ensure that its overall level of WTO commitments is unchanged. ${ }^{47}$

These additional conditions on the use of safeguards typically make them preferable, from an economic perspective, to anti-dumping and countervailing measures. ${ }^{48}$ However, perhaps in part because of these additional conditions (and the strict way in which the WTO Appellate Body has interpreted the Safeguards Agreement), Members in fact use safeguards far less frequently than anti-dumping or countervailing measures. ${ }^{49}$ Safeguards also still raise economic concerns in that, for example, they may encourage lobbying of governments by domestic industries in the hope of longterm protection rather than the temporary protection intended, ${ }^{50}$ and they tend to 'delay the contraction' of declining or uncompetitive industries. ${ }^{51}$ In addition, safeguards are central to the ambiguity surrounding the relationship between trade remedies and RTAs in the WTO. In particular, no authoritative decision or judgment exists as to whether WTO Members are allowed or required to exclude RTA partners from the application of safeguards, as discussed further below. ${ }^{52}$

Finally, safeguards suffer from a loophole in connection with the WTO dispute settlement system. A Member imposing a safeguard on the basis of an absolute increase in imports need not provide compensation to affected exporting Members for the first three years, ${ }^{53}$ and a safeguard found to be imposed contrary to WTO rules will not need to be remedied until the end of the reasonable period of time for compliance (which may be 15 months or more from the date of adoption of the relevant Panel and Appellate Body Reports), ${ }^{54}$ and then only on a prospective basis. Before that time, a violation may be maintained without being subject to retaliation in the form of suspension of concessions by the complaining Member. Although this feature is characteristic of WTO dispute settlement generally, it is of particular concern in the context of safeguards, because these are intended as emergency

\footnotetext{
46 Safeguards Agreement, Articles 7.1, 7.2, 2.2 (but see exceptions in Articles 5.2 and 9); Panel Report, Argentina - Footwear (EC), [8.84]. See the discussion in section IVB(iii) below concerning Article 2.2 of the Safeguards Agreement.

47 Safeguards Agreement, Articles 8, 12.3.

48 Chad Bown, 'Why are Safeguards Under the WTO So Unpopular?' (2002) 1 World Trade Review 47, 50-51. See also WTO, World Trade Report 2009 (WTO: Geneva, 2009) xv, 47-49.

49 Chad Bown, 'Why are Safeguards Under the WTO So Unpopular?' (2002) 1 World Trade Review 47, 47-48; Petros Mavroidis, Patrick Messerlin and Jasper Wauters, The Law and Economics of Contingent Protection in the WTO (Cheltenham: Edward Elgar, 2008) 465; Chad Bown and Meredith Crowley, 'Safeguards' in Patrick Macrory, Arthur Appleton and Michael Plummer (eds), The World Trade Organization: Legal, Economic and Political Analysis (New York: Springer, 2005) 43, 57, 61; WTO, World Trade Report 2009 (WTO: Geneva, 2009) xx.

50 Petros Mavroidis, Patrick Messerlin and Jasper Wauters, The Law and Economics of Contingent Protection in the WTO (Cheltenham: Edward Elgar, 2008) 475.

51 Alan Sykes, 'International Trade: Trade Remedies' in Andrew Guzman and Alan Sykes (eds), Research Handbook in International Economic Law (Cheltenham: Edward Elgar, 2007) 62, 75. See also Michael Trebilcock and Robert Howse, The Regulation of International Trade (New York: Routledge, $3^{\text {rd }}$ ed, 2005) 313-314.

52 See part IVB(iii).

53 Safeguards Agreement, Article 8.3.

54 Understanding on Rules and Procedures Governing the Settlement of Disputes, LT/UR/A2/DS/U/1 (signed 15 April 1994, entered into force 1 January 1995) ('DSU’), Article 21.3(c).
} 
measures imposed only on a temporary basis anyway. By the time the dispute settlement process is complete, the safeguards may have already been in place for a significant portion of the usual four-year period, ${ }^{55}$ with the result that the domestic industry gets 'free' protection for that temporary period regardless of whether the safeguards comply with WTO rules. ${ }^{56}$

If anti-dumping and countervailing measures are to be ultimately eliminated in the WTO, itself a controversial position, then Members may need to retain the ability to impose safeguards in order to provide a safety net and so prevent a reversal of the liberalisation gains that have been made over the last half century. However, the quirk of WTO dispute settlement should be remedied so that Members cannot maintain illegal safeguards for several years without consequence. These changes would likely render the use of safeguards even more unpopular, but it is crucial if trade remedies are to be restricted to legitimate purposes and no longer used as protectionist devices. Furthermore, it could be countered by other changes designed to make safeguards practically workable. As highlighted above, safeguards are intended as 'adjustment policies in order to become competitive, avoid a social or political crisis, and provide political room for the acceptance by the people of the rest of the WTO rules', but the Appellate Body's current jurisprudence makes it extremely difficult, if not impossible, for Members to impose safeguards consistently with WTO rules. ${ }^{57}$ Specifically, for reasons ably explained elsewhere, the Appellate Body's invented 'parallelism' requirement ${ }^{58}$ should be abolished, ${ }^{59}$ and its stringent conditions concerning matters such as 'unforeseen developments' 60 and 'non-attribution' ${ }^{61}$ revised. As detailed below, ${ }^{62}$ Members should also be reassured that they are entitled to exclude RTA partners from global safeguards, subject to certain conditions.

\footnotetext{
55 Safeguards Agreement, Article 7.1.

56 See, eg, Appellate Body Report, US - Steel Safeguards; 'Sparks fly over steel', The Economist, 15 November 2003, Vol 369, Iss 8350, p 78; Office of the Press Secretary, White House, 'Statement by the President' (Press Release, 4 December 2003).

57 Olivier Prost and Erwan Berthelot, 'Agreement on Safeguards, Article 2' in Rüdiger Wolfrum, Peter-Tobias Stoll and Michael Koebele (eds), Max Planck Commentaries on World Trade Law Volume 4: WTO - Trade Remedies (Leiden: Martinus Nijhoff, 2008) 264, 286; see also Alan Sykes, 'The Persistent Puzzles of Safeguards: Lessons from the Steel Dispute' (2004) 7(3) Journal of International Economic Law 523, 524, 563; Alan Sykes, 'The Fundamental Deficiencies of the Agreement on Safeguards: A Reply to Professor Lee’ (2006) 40(5) Journal of World Trade 979, 979980.

58 Appellate Body Report, Argentina - Footwear (EC), [111]-[112]; Appellate Body Report, US Line Pipe, [181]; Appellate Body Report, US - Steel Safeguards, [448]-[453]; Appellate Body Report, US - Wheat Gluten, [96].

59 Joost Pauwelyn, ‘The Puzzle of WTO Safeguards and Regional Trade Agreements' (2004) 7(1) Journal of International Economic Law 109, 119-124.

60 Yong-Shik Lee, 'Not Without a Clue: Commentary on "the Persistent Puzzles of Safeguards"' (2006) 40(2) Journal of World Trade 385, 390. Cf Alan Sykes, 'The Fundamental Deficiencies of the Agreement on Safeguards: A Reply to Professor Lee’ (2006) 40(5) Journal of World Trade 979, 993994.

61 Alan Sykes, 'The Fundamental Deficiencies of the Agreement on Safeguards: A Reply to Professor Lee’ (2006) 40(5) Journal of World Trade 979, 984-985.

62 See section IVB(iii).
} 
As foreshadowed in the introduction above, ${ }^{63}$ the problem of trade remedies is exacerbated whenever countries face difficult economic circumstances, because the pressure for protection of domestic industries intensifies. ${ }^{64}$ The current global financial climate may thus multiply the rates of applications for and imposition of anti-dumping, countervailing and safeguard measures. Indeed, although it may be too early to assess the full effects of the global financial crisis, it does appear to be having some impact on the imposition of trade remedies.

Based on Members' reports, the WTO Secretariat identified a 28\% increase in the number of new anti-dumping investigations in 2008 compared to 2007, and a 29\% increase in the number of new anti-dumping measures during the same period. ${ }^{65}$ Also based on Members' reports, the number of countervailing investigations exhibited a 27\% increase from 2007 and 2008, while the number of countervailing measures imposed shot from 2 in 2007 to 11 in 2008: an increase of $450 \%{ }^{66}$ A joint report issued under the responsibility of Pascal Lamy (Director-General of the WTO), Angel Gurría (Secretary-General of the Organisation for Economic Co-operation and Development ('OECD')) and Supachai Panitchpakdi (Secretary-General of the United Nations Conference on Trade and Development ('UNCTAD') and former WTO Director-General) indicates that the number of new safeguard investigations by G20 countries has increased considerably from 2 in the first half of 2008 to 16 in the first half of 2009. ${ }^{67}$ Finally, Chad Bown's Global Antidumping Database reveals an 18.8\% increase in the initiation of anti-dumping, countervailing and safeguard investigations in the first quarter of 2009 compared to the first quarter of 2008, a 12.1\% increase in the second quarter of 2009 compared to the second quarter of 2008, and a 52.6\% increase in the third quarter of 2009 compared to the third quarter of $2008 .{ }^{68}$ These increases may be one example of the 'murky protectionism' that some commentators

63 See above $\mathrm{n} 3$ and corresponding text.

64 See WTO, World Trade Report 2009 (WTO: Geneva, 2009) xxi, xxiii.

65 WTO Press Release 556, 'WTO Secretariat reports increase in new anti-dumping investigations' (7 May 2009); AD Initiations: By Reporting Member From: 01/01/95 To: 31/12/08, at < www.wto.org/ english/tratop_e/adp_e/ad_init_rep_member_e.pdf>, last accessed 22 October 2009; $A D$ Measures: By Reporting Member From: 01/01/95 To: 31/12/08, at <www.wto.org/english/tratop_e/adp_e/ ad_meas_rep_member_e.pdf $>$, last accessed 22 October 2009.

${ }_{66}$ CV Initiations: By Reporting Member From: 01/01/95 To: 31/12/08, at <www.wto.org/english /tratop_e/scm_e/cvd_init_rep_member_e.pdf $>$, last accessed 7 June 2009; CV Measures: By Reporting Member From: 01/01/95 To: 31/12/08, at < www.wto.org/english/tratop_e/scm_e/cvd_meas_rep_ member_e.pdf $>$, last accessed 7 June 2009.

${ }^{67}$ WTO-OECD-UNCTAD, Report on G20 Trade and Investment Measures (14 September 2009) 12.

${ }^{68}$ Chad Bown, 'Protectionism Increases and Spreads: Global Use of Trade Remedies Rises by 18.8\% in First Quarter 2009', A Monitoring Update to the Global Antidumping Database (11 May 2009) 1; Chad Bown, 'Protectionism Continues its Climb: Spike in "Safeguard” Use is Major Contributor to 12.1\% Global Increase in Industry Demands for New Import Restrictions during Second Quarter of 2009’, $A$ Monitoring Update to the Global Antidumping Database (23 July 2009) 1; Chad Bown, 'The Pattern of Antidumping and Other Types of Contingent Protection', PREMnotes Number 144 (October 2009) 1. These statistics include China-specific safeguards (see note 42 and corresponding text above). See also Chad Bown, 'Protectionism is on the rise: antidumping investigations' in Richard Baldwin and Simon Evenett (eds), The collapse of global trade, murky protectionism, and the crisis: Recommendations for the G20 (London: Centre for Economic Policy Research, 2009) 55. 
fear is developing as a result of the crisis, ${ }^{69}$ rendering all the more important the quest to combat trade remedies.

\section{RTAS AS MODELS FOR REDUCING TRADE REMEDIES?}

This part details and explores RTAs that include commitments by the parties not to impose trade remedies on each other. Commitments of this kind represent an improvement on existing WTO rules from an economic perspective, and they suggest that practical and political obstacles to reducing the use of trade remedies are not insurmountable. Although the vast majority of RTAs maintain the WTO exceptions allowing trade remedies, some adopt an alternative approach. Below, I first survey the general RTA response to trade remedies, which is to maintain WTO trade remedy provisions with no or only minor modifications. I describe these as 'WTO-equivalent' RTAs. I then turn to examine in more detail a number of RTAs that provide more substantial modifications to WTO rules, reducing the application of anti-dumping, countervailing or safeguard measures between RTA partners or limiting their degree. ${ }^{70}$ These are 'WTO-plus' RTAs in the sense that they represent more stringent commitments to liberalise trade between the parties than apply generally between WTO Members under the GATT 1994 and its associated trade remedy agreements. However, as discussed further below, these RTAs will not necessarily lead to greater trade liberalisation or less trade distortion at a global level.

\section{A WTO-Equivalent RTAs}

As already stated, most RTAs do not vary the general WTO rights to impose trade remedies, or they modify these rights in only a minor way. Annex 1 below summarises 118 RTAs that fall within this description.

The 25 RTAs listed in Category 1 of Annex 1 make no mention of WTO antidumping, countervailing, or safeguard measures (thus leaving the WTO rules unmodified, and maintaining rights to impose trade remedies in accordance with those rules) or make no significant changes to the WTO trade remedy provisions under examination in this paper. Category 1 therefore contains the most 'WTO-equivalent' of the RTAs reviewed. However, most of these agreements concern the 12 members of the Commonwealth of Independent States-Armenia, Azerbaijan, Belarus, Georgia, Kazakhstan, Kyrgyz Republic, Moldova, Russian Federation, Tajikistan, Turkmenistan, Ukraine, Uzbekistan—many of which are not yet WTO Members. ${ }^{71}$

\footnotetext{
69 Richard Baldwin and Simon Evenett (eds), The collapse of global trade, murky protectionism, and the crisis: Recommendations for the G20 (London: Centre for Economic Policy Research, 2009). See also WTO, World Trade Report 2009 (WTO: Geneva, 2009) 160.

70 For earlier WTO analysis of RTA trade remedy provisions, see WTO Committee on Regional Trade Agreements, Inventory of Non-Tariff Provisions in Regional Trade Agreements: Background Note by the Secretariat, WT/REG/W/26 (5 May 1998) 15-22.

71 At the time of writing, Azerbaijan, Belarus, Kazakhstan, Russian Federation, Tajikistan, Turkmenistan, and Uzbekistan are not WTO Members, although all of these apart from Turkmenistan are recognised as observer governments in the WTO and are in the process of accession to the WTO: see $<$ www.wto.org/english/thewto_e/acc_e/acc_e.htm $>$ and $<$ www.wto.org/english/thewto_e/whatis_e /tif_e/org6_e.htm>, last accessed 8 June 2009. For further discussion of integration in this region, see Sherzod Shadikhodjaev, 'Trade Integration in the CIS Region: A Thorny Path Towards a Customs
} 
Some of the RTAs in Category 1 contain procedural modifications to the WTO rules. For example, the Euro-Mediterranean Association Agreement between the European Communities and Egypt ${ }^{72}$ requires consultations before imposing safeguard measures under the WTO agreements, ${ }^{73}$ and the Melanesian Spearhead Group Trade Agreement ${ }^{74}$ requires consultations before imposing either anti-dumping or countervailing measures. ${ }^{75}$

\section{(ii) Category 2: Introduction of Bilateral Safeguards}

The 28 RTAs listed in Category 2 of Annex 1 either do not mention anti-dumping or countervailing measures or explicitly preserve the parties' existing rights to impose these measures under WTO rules or domestic legislation. For example, Article 6.2.1 of the Trans-Pacific Strategic Economic Partnership Agreement ('Trans-Pacific SEP'), between Brunei Darussalam, Chile, New Zealand ('NZ'), and Singapore, ${ }^{76}$ states:
Nothing in this Agreement affects the rights and obligations of the Parties under Article VI of GATT 1994, the Agreement on Implementation of Article VI of the General Agreement on Tariffs and Trade 1994 which is part of the WTO Agreement (Antidumping Agreement) and the Agreement on Subsidies and Countervailing Measures which is part of the WTO Agreement (SCM Agreement) with regard to the application of antidumping and countervailing duties or any amendments or provisions that supplement or replace them.

The Category 2 RTAs all provide additional rules on bilateral safeguards (that is, safeguards applied between RTA partners as opposed to global safeguards applied to all WTO Members in accordance with GATT Article XIX and the Safeguards Agreement). These bilateral safeguards are sometimes described as 'tariff snapbacks', because they involve reversion to MFN tariff rates in particular circumstances. Sometimes bilateral safeguards are allowed for a transitional period only and sometimes only in relation to specific products or for specific purposes. For instance, Article 6.1.1 of the Trans-Pacific SEP preserves the parties' WTO rights under GATT Article XIX and the Safeguards Agreement, and a separate chapter allows Chile to apply a 'special safeguard measure to a limited number of specified sensitive agricultural goods' where the quantity of imports of the relevant good exceeds a particular 'quantity trigger level'. 77 These kinds of RTAs, in allowing the imposition of global as well as bilateral safeguards, have the potential to increase the use of 'trade remedies', broadly defined, among WTO Members. Although some of the agreements specify that global and bilateral safeguards cannot both be applied in the

Union’ (2009) Journal of International Economic Law (advance access version published online 22 May 2009).

72 Signed 25 June 2001, entered into force 1 June 2004.

73 Article 24.

74 Signed 22 July 1993, entered into force 22 July 1993.

75 Article 14

76 Signed by New Zealand, Chile and Singapore on 18 July 2005 and by Brunei Darussalam on 2 August 2005; entered into force for New Zealand and Singapore on 1 May 2006, for Chile on 8 November 2006, and for Brunei Darussalam on a provisional basis on 12 June 2006.

77 Trans-Pacific SEP, Articles 3.13.1, 3.13.5. See n 41 above regarding WTO safeguards relating to agriculture. See also OECD, 'Regional Trading Arrangements and the Multilateral Trading System: Agriculture’, OECD Trade Policy Working Papers No 15 (OECD: Paris, 2005) 8-9. 
same instance, ${ }^{78}$ these kinds of RTAs do not provide much of a model in demonstrating how to reduce the use of trade remedies in the WTO.

\section{(iii) Category 3: Procedural Modifications and Bilateral Safeguards}

The 66 RTAs listed in Category 3 of Annex 1 make procedural changes to the application of WTO trade remedies and also provide additional rules regarding the application of bilateral safeguards. As with the procedural changes mentioned above in relation to Category 1, these RTAs generally provide for consultations before applying trade remedies. Other procedural changes in these RTAs include enhanced notification requirements before applying trade remedies. ${ }^{79}$ Lee explains how the Republic of Korea largely failed in its attempts to have similar procedural and more substantive requirements included in the United States - Korea Free Trade Agreement $^{80}$ in respect of anti-dumping and countervailing measures. ${ }^{81}$ Although these additional procedural hurdles may encourage RTA partners to reach a mutually agreed solution rather than imposing trade remedies, these are fairly soft obligations and do not assure that result.

\section{B WTO-Plus RTAs}

In this section I examine RTAs that substantively modify the WTO rules on trade remedies by restricting or eliminating their use in particular circumstances. Annex 2 lists 32 RTAs that exclude the application of anti-dumping, countervailing and/or safeguard measures as between RTA partners, with some RTAs appearing in more than one column because they limit more than one type of trade remedy.

The first column of Annex 2 contains eight RTAs that abolish anti-dumping measures between RTA partners. One positive case study is the Australia New Zealand Closer Economic Relations Trade Agreement ('ANZCER'), ${ }^{82}$ which was signed in 1983 and amended in 1988 by the Protocol to the Australia New Zealand Closer Economic Relations-Trade Agreement on Acceleration of Free Trade in Goods ('ANZ Protocol'), ${ }^{83}$ under which the parties agree to eliminate anti-dumping measures on goods originating in each other's territory. ${ }^{84}$ Interestingly, this agreement allows the parties to continue to impose countervailing measures on each other's imports, but

\footnotetext{
78 See, eg, Agreement on Trade in Goods under the Framework Agreement on Comprehensive Economic Cooperation Among the Governments of the Member Countries of the Association of Southeast Asian Nations ('ASEAN') and the Republic of Korea (signed 24 August 2006), Article 9.10. Similarly, Article 5.8 of the Agreement on Agriculture precludes recourse to both the special safeguard under that agreement and global safeguards under Article XIX of the GATT 1994. See above n 42 and corresponding text.

79 See, eg, ASEAN Protocol on Notification Procedures (signed 8 October 1998), Article 1.

80 Signed 30 June 2007.

81 Yong-Shik Lee, 'The Beginning of Economic Integration Between East Asia and North America? - Forming the Third Largest Free Trade Area Between the United States and the Republic of Korea' (2007) 41(5) Journal of World Trade 1091, 1112-1113.

82 Signed 28 March 1983, deemed to have entered into force 1 January 1983.

83 Signed 18 August 1988, entered into force 18 August 1988.

84 Article 4.
} 
only 'when no mutually acceptable alternative course of action has been determined by the Member States'. 85

In certain European and Chinese agreements, ${ }^{86}$ abolition of anti-dumping measures is similarly associated with deep integration (characterised by 'harmonized or common behind-the-border measures', 'arrangements that allow for free or freer movement of capital and labour', 'monetary union or the adoption of a single currency', or political integration). ${ }^{87}$ However, RTAs with a lower level of integration have also managed to abolish anti-dumping measures, ${ }^{88}$ often linking the abolition directly with the implementation or harmonisation of effective competition rules. For example, under the Free Trade Agreement between the [European Free Trade Association ('EFTA')] States and the Republic of Chile: ${ }^{89}$

1. A Party shall not apply anti-dumping measures as provided for under the WTO Agreement on Implementation of Article VI of the GATT 1994 in relation to goods of a Party'.

2. The Parties recognise that the effective implementation of competition rules may address economic causes leading to dumping. ${ }^{90}$

De Araujo, Macario and Steinfatt conclude that the degree of integration is a more important factor in allowing for the abolition of anti-dumping measures in RTAs than is the creation of a common competition policy or competition rules to replace antidumping at the international level, noting that these different regulatory policies have different objectives. In contrast, they explain the RTA between Canada and Chile ${ }^{91}$ as involving the replacement of anti-dumping with bilateral safeguard measures. ${ }^{92}$ Hoekman and others reach a similar conclusion. ${ }^{93}$ If correct, this is a positive sign,

\footnotetext{
85 Article 16.1(c).
}

86 Closer Economic Partnership Arrangement between China and Hong Kong, China (signed 29 June 2003, entered into force 1 January 2004), Article 7; Closer Economic Partnership Arrangement between China and Macao, China, (signed 17 October 2003, entered into force 1 January 2004), Article 7; Consolidated Version of the Treaty Establishing the European Community [2006] OJ C 321 E/1 ('EC Treaty'), Articles 23, 25; Consolidated Version of the Convention Establishing the European Free Trade Association (signed 21 June 2001, entered into force 1 June 2002) ('EFTA'), Article 36; cf Agreement on the European Economic Area (signed 2 May 1992, entered into force 1 January 1994) ('EEA'), Article 26 (anti-dumping measures abolished in most sectors, pursuant to Protocol 13). 87 Robert Teh, Thomas Prusa and Michele Budetta, 'Trade Remedy Provisions in Regional Trade Agreements', WTO Staff Working Paper ERSD-2007-03 (WTO: Geneva, 2007) 28-29.

${ }_{88}$ See, eg, Free Trade Agreement between Canada and Chile (signed 5 December 1996, entered into force 5 July 1997), Article M-01.

89 Signed 26 June 2003, entered into force 1 December 2004.

90 Article 18. See also Free Trade Agreement between the EFTA States and Singapore (signed 26 June 2002, entered into force 1 January 2003), Article 16.

${ }_{91}$ Free Trade Agreement between Canada and Chile (signed 5 December 1996, entered into force 5 July 1997), Article M-01.

92 José de Araujo, Carlo Macario and Karsten Steinfatt, 'Antidumping in the Americas' (2001) 35(4) Journal of World Trade 555, 568-570. See also José Rivas-Campo and Rafael Benke, 'FTAA Negotiations: Short Overview’ (2003) 6(3) Journal of International Economic Law 661, 672.

93 Bernard Hoekman, 'Competition Policy and Preferential Trade Agreements', World Bank Working Paper (World Bank: Washington DC, 2002) 14; Bernard Hoekman, 'Free Trade and Deep Integration: Antidumping and Antitrust in Regional Agreements, Policy Research Working Paper (World Bank: Washington DC, 1998) 31; Robert Teh, Thomas Prusa and Michele Budetta, 'Trade Remedy Provisions in Regional Trade Agreements’, WTO Staff Working Paper ERSD-2007-03 (WTO: Geneva, 2007) 27-29. 
since it means that agreement on competition rules at the multilateral level is not necessarily a precondition to the abolition of anti-dumping measures among WTO Members. Progress on the competition front would certainly not hinder the goal of abolishing anti-dumping, but, as already noted, neither of these issues is currently on the WTO agenda. ${ }^{94}$ Agreement on competition policy beyond national borders is difficult. In the context of the ANZCER, Taylor concludes that ' $[t]$ he success of replacing anti-dumping laws with competition law ... appears to be linked with the high degree of similarity in business practices, legal systems and existing competition law, along with similar social, economic and cultural backgrounds'.95 Gradual liberalisation within an RTA over an extended period of time may also allow the industries in the partners' markets to adjust and become more closely integrated, facilitating harmonisation of competition law and policy.

One concern about restricting anti-dumping measures between RTA parties is that non-parties will suffer greater discrimination with respect to anti-dumping or be subject to more anti-dumping measures by those parties, distorting and restricting international trade. ${ }^{96}$ Teh, Prusa and Budetta express this concern, after determining that 56 in a survey of 74 RTAs either abolish anti-dumping measures or contain specific anti-dumping provisions. ${ }^{97}$ The assumption that WTO Members 'need' to engage in a certain degree of protectionism and that this will manifest in the form of anti-dumping measures against imports from one country or another could be valid. However, little empirical evidence exists to support the authors' hypothesis regarding the impact on non-RTA parties of restricting intra-RTA anti-dumping measures, and further economic and statistical analysis is required to assess this conclusion.

Moreover, Members do not impose anti-dumping duties on an MFN basis anyway; nor do the WTO rules require them to do so. Rather, a Member imposing these duties in respect of a given product following an anti-dumping investigation must simply do so 'on a non-discriminatory basis on imports of such product from all sources found to be dumped and causing injury', ${ }^{98}$ except for imports from sources that have provided undertakings to revise their prices in accordance with Article 8 of the Anti-Dumping Agreement. An anti-dumping investigation is initiated upon an application by or on behalf of the domestic industry or (more rarely) by the investigating authorities themselves, in both cases subject to the existence of sufficient evidence of dumping,

\footnotetext{
94 See WTO, Doha Work Programme: Decision Adopted by the General Council on 1 August 2004, WT/L/579 (2 August 2004) [1(g)] (removing competition from the Doha Work Programme). See also above $\mathrm{n} 24$.

95 Martyn Taylor, International Competition Law: A New Dimension for the WTO? (Cambridge: Cambridge University Press, 2006) 274-276.

96 See, eg, Dukgeun Ahn, 'Foe or Friend of GATT Article XXIV: Diversity in Trade Remedy Rules' (2008) 11(1) Journal of International Economic Law 107, 125-126; Matthew Schaefer, 'Ensuring that Regional Trade Agreements Complement the WTO System: US Unilateralism a Supplement to WTO Initiatives?' (2007) 10(3) Journal of International Economic Law 585, 590.

97 Robert Teh, Thomas Prusa and Michele Budetta, 'Trade Remedy Provisions in Regional Trade Agreements', WTO Staff Working Paper ERSD-2007-03 (WTO: Geneva, 2007) 21. The authors find nine RTAs that abolish anti-dumping (including the EEA) and 47 with specific anti-dumping provisions (see 18-19). The authors reach a similar conclusion in Robert Teh, Thomas Prusa and Michele Budetta, 'Trade Remedy Provisions in Regional Trade Agreements' in Antoni Estevadeordal, Kati Suominen and Robert Teh (eds), Regional Rules in the Global Trading System (New York: Cambridge University Press, 2009) 166, 174-175.

98 Anti-Dumping Agreement, Article 9.2 (emphasis added).
} 
injury and causal link to justify the initiation of an investigation. ${ }^{99}$ The domestic industry may choose to target imports from particular countries and not others, in applying to the investigating authorities to commence an anti-dumping investigation. Similarly, Members with particular historical, political or economic ties may choose not to subject each other's imports to anti-dumping investigations, whether or not they have an RTA obligation to refrain from doing so (indeed, with the exception of the EC, the RTAs identified in column 1 of Annex 2 appeared to have little impact on the actual rate of anti-dumping investigations initiated or measures imposed with respect to RTA partners - that is, these partners were not frequent targets anyway). An RTA obligation would of course entrench this approach, removing the discretion of Members to decide from one case to the next whether to investigate imports from specific countries. Nevertheless, given the economic difficulties with anti-dumping measures highlighted earlier, without further investigation, this concern provides an insufficient basis on which to discourage RTAs that abolish anti-dumping measures or discount their potential value as a precedent in reducing anti-dumping measures on a broader scale.

The second column of Annex 2 contains the only four RTAs ${ }^{100}$ that abolish countervailing measures between RTA partners. This is somewhat surprising, given that, as noted above, WTO Members can challenge prohibited or actionable subsidies in the WTO dispute settlement system. It seems that this additional 'multilateral' avenue for obtaining a remedy is insufficient to encourage Members to forego the 'unilateral' avenue of countervailing measures, in the absence of a high degree of economic integration or a common approach to subsidies or 'state aid'. ${ }^{101}$ Teh, Prusa and Budetta speculate that Members may be reluctant to commit to reduce subsidies in RTAs because all WTO Members will reap benefit from this commitment, and so RTA partners are correspondingly reluctant to agree to eliminate countervailing measures. ${ }^{102}$

Any concerns about RTA abolition of countervailing duties leading to increased countervailing duties with respect to non-RTA WTO Members (that is, WTO Members not party to the relevant RTA) is subject to the considerations outlined above in relation to anti-dumping: in particular, countervailing duties are not imposed on an MFN basis against imports of the relevant product from all sources. Article 19.3

99 Anti-Dumping Agreement, Article 5.1, 5.2, 5.6.

100 Closer Economic Partnership Arrangement between China and Hong Kong, China (signed 29 June 2003, entered into force 1 January 2004), Article 8; Closer Economic Partnership Arrangement between China and Macao, China, (signed 17 October 2003, entered into force 1 January 2004), Article 8; EC Treaty, Articles 23, 25; EFTA, Article 16.2; cf EEA, Article 26 (countervailing measures abolished in most sectors, pursuant to Protocol 13).

101 Cf Robert Teh, Thomas Prusa and Michele Budetta, 'Trade Remedy Provisions in Regional Trade Agreements', WTO Staff Working Paper ERSD-2007-03 (WTO: Geneva, 2007) 22 (linking this trend to a reluctance to reduce or eliminate subsidies as part of an RTA); David Gantz, Regional Trade Agreements: Law, Policy and Practice (Durham, North Carolina: Carolina Academic Press, 2009) 323 (suggesting that the absence of common subsidy policy weakens the argument for eliminating countervailing measures in RTAs).

102 Robert Teh, Thomas Prusa and Michele Budetta, 'Trade Remedy Provisions in Regional Trade Agreements' in Antoni Estevadeordal, Kati Suominen and Robert Teh (eds), Regional Rules in the Global Trading System (New York: Cambridge University Press, 2009) 166, 207. 
of the SCM Agreement merely requires that Members imposing countervailing duties in respect of any given product do so 'on a non-discriminatory basis on imports of such product from all sources found to be subsidized and causing injury', ${ }^{103}$ except for imports subject to undertakings in accordance with Article 18 of the SCM Agreement. If a Member does not subject imports from a particular exporting country to a countervailing duty investigation, it need not (and cannot) impose countervailing duties on those imports. This means that, even in the absence of an RTA, Members are free to decide which Members to target in a countervailing duty investigation and which to exclude. Thus, an RTA obligation to shield RTA partners from countervailing duties will not necessarily increase the application of countervailing duties to imports of other countries.

\section{(iii) Eliminating Safeguards}

The third column of Annex 2 lists 30 RTAs that allow or require RTA partners to exclude the products of other RTA partners from the application of global safeguards pursuant to GATT Article XIX and the Safeguards Agreement, on certain conditions. A number of these RTAs allow RTA partners to impose bilateral safeguards as between themselves, and/or modify the WTO rules regarding anti-dumping or countervailing measures, including by imposing the 'lesser-duty rule' in anti-dumping proceedings or raising the de minimis dumping margin from $2 \%$ to $5 \%$. ${ }^{104}$ Some RTAs not included in the Annexes contain similar substantive modifications to WTO anti-dumping rules. ${ }^{105}$ Other RTAs that are being negotiated or have not yet entered into force contemplate restricting the application of global safeguards to RTA partners while allowing bilateral safeguards. ${ }^{106}$

As an example of how RTA partners restrict the availability of global safeguards as between themselves, the North American Free Trade Agreement ('NAFTA'), ${ }^{107}$ between Canada, Mexico and the US, provides:

Any Party taking an emergency action under Article XIX or any such agreement shall exclude imports of a good from each other Party from the action unless:

\footnotetext{
103 Emphasis added.

104 See, eg, Singapore - Australia Free Trade Agreement (signed 17 February 2003, entered into force 28 July 2003), Article 8.2(b); Agreement between the Government of the Hashemite Kingdom of Jordan and the Government of the Republic of Singapore on the Establishment of a Free Trade Area (signed 16 May 2004, entered into force 22 August 2005), Article 2.8.1(a). Cf Anti-Dumping Agreement, Articles 5.8, 9.1. Under these provisions, Members' authorities must terminate anti-dumping investigations when the dumping margin is de minimis, ie less than 2 per cent expressed as a percentage of the export price, and Members may impose an anti-dumping duty up to the amount of the dumping margin. Applying the 'lesser duty rule', which is recognised as 'desirable' but not required under the Anti-Dumping Agreement, means imposing an anti-dumping duty only to the extent necessary to remove injury to the domestic industry, where that can be achieved without imposing a duty at the level of the full margin of dumping.

105 See, eg, Agreement between the EFTA States and the Republic of Korea (signed 15 December 2005, entered into force 1 September 2006), Article 2.10.1; Free Trade Agreement between Korea and Singapore (signed 4 August 2005, entered into force 1 March 2006), Article 6.2.3.

${ }_{106}$ See, eg, Government of Peru, Ministry of Foreign Commerce and Tourism, Executive Summary: Peru - EFTA Free Trade Agreement, Second Round of Negotiations in Lima, Peru (27 to 31 August 2007) 39; Free Trade Agreement between the Republic of Colombia and the EFTA States (signed 25 November 2008), Articles 2.17-2.18.

107 Signed 17 December 1992, entered into force 1 January 1994.
} 
(a) imports from a Party, considered individually, account for a substantial share of total imports; and

(b) imports from a Party, considered individually, or in exceptional circumstances imports from Parties considered collectively, contribute importantly to the serious injury, or threat thereof, caused by imports. ${ }^{108}$

NAFTA also provides for bilateral safeguards for a transitional period, ${ }^{109}$ as well as independent bi-national panels to assess final determinations in anti-dumping and countervailing duty cases against domestic laws ${ }^{110}$ (a compromise flowing from Canada's unsuccessful attempt to have anti-dumping measures eliminated from the earlier Canada - United States Free Trade Agreement). ${ }^{111}$

The parties to the New Zealand - China Free Trade Agreement ${ }^{112}$ (the first developed country RTA with China) agree that, when imposing safeguard measures pursuant to GATT Article XIX and the Safeguards Agreement, they 'may exclude imports of an originating good from the other Party from the action if such imports are noninjurious'. ${ }^{113}$ The parties to this RTA otherwise 'maintain their rights and obligations' under Articles VI and XIX of GATT 1994 and the Anti-Dumping Agreement, SCM Agreement and Safeguards Agreement, ${ }^{114}$ although they also agree not to take any anti-dumping action 'in an arbitrary or protectionist manner'. ${ }^{115}$

According to Baldwin, Evenett and Low, RTAs under which 'parties have agreed to exempt other parties from any global safeguards that they impose under the respective WTO agreement' provide 'an example of exactly the opposite of multilateralizing regionalism, with RTAs undermining an established non-discriminatory multilateral norm'. ${ }^{116}$ This conclusion assumes, of course, that the WTO rules allow Members to impose global safeguards only on a non-discriminatory basis, an issue discussed further below. ${ }^{117}$ However, if RTAs can constitute an exception to the MFN rule in relation to safeguards under WTO law, then RTAs that allow the exclusion of RTA products from a global safeguard do not alter this position, and even RTAs that

\footnotetext{
108 Article 802.1 (emphasis added).

109 Article 801.

110 Chapter 19, Article 1904. See generally Bruce Blonigen, 'The Effects of NAFTA on Antidumping and Countervailing Duty Activity’ (2005) 19(3) The World Bank Economic Review 407; Gustavo Vega-Canovas, 'Disciplining Anti-Dumping in North America: Is NAFTA Chapter Nineteen Serving its Purpose?' (1997) 14 Arizona Journal of International and Comparative Law 479; Gilbert Winham and Heather Grant, 'Antidumping and Countervailing Duties in Regional Trade Agreements: CanadaUS FTA, NAFTA and Beyond’ (1994) 3 Minnesota Journal of Global Trade 1. See also Michael Hart, Decision at Midnight: Inside the Canada-US Free-Trade Negotiations (Vancouver: UBC Press, 1994) 388.

111 Michael Hart, 'Introduction' in Michael Hart (ed), Finding Middle Ground: Reforming the Antidumping Laws in North America (Ottawa, Centre for Trade Policy and Law, 1997) 1, 7.

112 Free Trade Agreement Between The Government of New Zealand And The Government of the People's Republic of China, signed 7 April 2008, entered into force 1 October 2008.

113 Article 64.1 (emphasis added).

114 Article 61.1.

115 Article 62.1.

116 Richard Baldwin, Simon Evenett and Patrick Low, 'Beyond tariffs: multilateralizing non-tariff RTA commitments’ in Richard Baldwin and Patrick Low (eds), Multilateralizing Regionalism (Cambridge: Cambridge University Press, 2009) 79, 120.

117 See section IVB(iii).
} 
require such exclusion simply remove Members' discretion in imposing safeguards (but these RTAs will still need to comply with Article XXIV:5 of the GATT 1994). ${ }^{118}$

Nevertheless, regardless of the WTO requirements, the practical impact of allowing or requiring Members to exclude imports of RTA partners from the application of a global safeguard deserves further empirical and economic investigation. In one study, Bown and McCulloch concluded that 'country exemptions for PTA members and small developing-country suppliers have a discriminatory impact of redistributing import market shares toward these suppliers, at least on average, at the expense of other exporting countries'. ${ }^{119}$ However, the overall impact of excluding RTA partners from global safeguards is likely to differ depending on whether the relevant RTA provides for RTA partners to impose bilateral safeguards on each other's products. All other things being equal, an RTA that precludes a party from imposing bilateral or global safeguards on other RTA parties will be less restrictive of intra-RTA trade than an RTA that allows for bilateral but not global safeguards between RTA parties, even if neither RTA affects the parties' rights to impose global safeguards on other WTO Members. On the other hand, an RTA that prohibits bilateral and global safeguards may increase trade diversion away from non-RTA WTO Members, distorting international trade.

As indicated in Annex 2, only five of the RTAs surveyed exclude both bilateral and global safeguards as between the parties. ${ }^{120}$ This kind of arrangement is generally associated with deeper integration, as in the European Communities ('EC'), ${ }^{121}$ MERCOSUR (the Mercado Común del Cono Sur between Argentina, Brazil, Paraguay, and Uruguay), ${ }^{122}$ and ANZCER. ${ }^{123}$ However, Singapore's RTAs with both Australia and NZ demonstrate that this level of liberalisation is possible even in the absence of full or deep economic integration, ${ }^{124}$ providing a useful bilateral lesson for the multilateral stage.

\section{Initial Conclusions}

Annex 2 reveals only one RTA - the Treaty Establishing the EC — that has abolished all three forms of trade remedies among its members: anti-dumping, countervailing, and safeguard measures. The number of RTAs excluding either anti-dumping, countervailing, or bilateral and global safeguard measures is also very low (eleven in total), suggesting that the general reluctance across the WTO Membership to

\footnotetext{
118 See below section IVB(ii).

119 Chad Bown and Rachel McCulloch, 'Nondiscrimination and the WTO Agreement on Safeguards' (2003) 2(3) World Trade Review 327, 347. See also 343-345.

120 These RTAs sometimes retain provisions for emergency measures to address balance of payment difficulties. See n 41 above regarding WTO balance of payments safeguards.

121 EC Treaty, Articles 3.1(a), 23, 25, 28.

122 MERCOSUR Free Trade Agreement (signed 26 March 1991, entered into force 29 November 1991), Annex IV, Article 5. Anti-dumping and countervailing measures are allowed within MERCOSUR: MERCOSUR Council, Decision 22/02, Defensa Comercial Intrazona (6 December 2002).

123 ANZ Protocol, Articles 1.1, 2.1 (eliminating tariffs, tariff quotas and quantitative import restrictions from 1 July 1990).

124 Singapore - Australia Free Trade Agreement (signed 17 February 2003, entered into force 28 July 2003), Article 9; Agreement between New Zealand and Singapore on a Closer Economic Partnership (signed 14 November 2000, entered into force 1 January 2001), Article 9.
} 
contemplate excluding these measures is reflected in RTAs across the globe. This highlights the difficulty in achieving agreement to eliminate trade remedies, even at a plurilateral level, as well as the different considerations applicable to each of the three forms, and the significance of broader and deeper integration in eliminating trade remedies. Thus, an advanced degree of intra-RTA trade liberalisation may be necessary before RTA partners will agree to remove trade remedies. Before that degree of liberalisation is achieved, trade remedies appear to play an important role in enabling liberalisation. In other words, RTA partners cannot typically agree on liberalisation beyond MFN levels without having trade remedies to fall back on. The common feature of bilateral safeguards (included in all Annex I Categories 2 and 3 RTAs, and most Annex II RTAs) demonstrates the significance of safeguards in particular in facilitating liberalisation, confirming the continued need for global safeguards in the WTO, albeit subject to a reformed regime as outlined above. ${ }^{125}$ In the next section, I examine another significant reason that may be fueling Members' reluctance to remove trade remedies in RTAs: uncertainty regarding the WTOconsistency of such an approach.

\section{LEgALity of RTAs Restricting TRADE REMEdiES}

In this section, I assess the legality of RTAs that restrict the use of trade remedies among RTA partners. In particular, do the WTO agreements prohibit RTA partners from applying trade remedies against each other or, conversely, do they permit or require RTA partners to do so? Put differently, are RTA provisions that preclude the application of trade remedies among RTA partners mandatory, permissible or prohibited under WTO rules? If WTO rules permit or require these provisions, RTAs may provide a useful framework for reducing trade remedies and a path towards trade remedy reduction in the WTO more broadly. As a preliminary step, I consider whether RTA partners are entitled to modify the WTO agreements amongst themselves (to restrict the use of trade remedies or otherwise) as a matter of public international law. I then turn to the implications of Article XXIV of the GATT 1994 for RTAs that restrict the application of safeguards among RTA partners. Safeguards provide the most complicated circumstances when it comes to restricting trade remedies in RTAs, due to the MFN rule reflected in Article 2.2 of the Agreement on Safeguards. I then turn to consider the implications of GATT Article XXIV for RTAs that restrict the application of anti-dumping or countervailing measures among RTA partners. Finally, I assess whether the Decision on Differential and More Favourable Treatment, Reciprocity, and Fuller Participation of Developing Countries ${ }^{126}$ ('Enabling Clause') affects these questions for RTAs among developing country Members.

\section{A Legality of Inter Se Modifications to the WTO Agreements}

If WTO Members are not entitled to make inter se modifications to the WTO agreements at all (that is, modifications amongst some Members only), then an RTA that removed parties' rights to impose trade remedies pursuant to WTO rules might amount to a prohibited modification, even if this particular modification would not otherwise violate individual WTO rules. Accordingly, it is worth considering first

\footnotetext{
125 See section IIB(ii).

126 L/4903, BISD 26S/203 (28 November 1979).
} 
whether inter se modifications are allowed in the WTO, before turning to the specific modification of removing trade remedy rights in RTAs.

\section{(i) Applicability of Article 41(1) of the VCLT in the WTO}

As a general matter, the question whether groups of WTO Members may make inter se modifications to the WTO agreements remains undetermined. Article 41(1) of the VCLT provides guidance on when inter se modifications are allowed. Article 41(1) provides:

Two or more of the parties to a multilateral treaty may conclude an agreement to modify the treaty as between themselves alone if:

(a) the possibility of such a modification is provided for by the treaty; or

(b) the modification in question is not prohibited by the treaty and:

(i) does not affect the enjoyment by the other parties of their rights under the treaty or the performance of their obligations;

(ii) does not relate to a provision, derogation from which is incompatible with the effective execution of the object and purpose of the treaty as a whole.

Panels and the Appellate Body have long recognised the interpretative provisions of Articles 31 to 33 of the VCLT as codifying or declaring customary international law. These provisions are therefore widely accepted as crucial in interpreting WTO agreements $^{127}$ in accordance with Article 3.2 of the WTO's Understanding on Rules and Procedures Governing the Settlement of Disputes (the 'Dispute Settlement Understanding' or 'DSU'), ${ }^{128}$ which indicates that one purpose of the WTO dispute settlement system is to 'clarify the existing provisions of [the WTO] agreements in accordance with customary rules of interpretation of public international law'.

As Article 41(1) is not concerned with interpretation, it falls outside the description in Article 3.2 of the DSU, and the Appellate Body has not included Article 41(1) in this characterisation of the VCLT as customary. Nevertheless, Article 41(1) has been recognised outside the WTO as constituting customary international law, ${ }^{129}$ along

\footnotetext{
127 See, eg, Appellate Body Report, US - Gasoline, 16-17; Appellate Body Report, EC - Computer Equipment, [84]; Appellate Body Report, EC-Sardines, [200]; Appellate Body Report, IndiaPatents (US), [46]; Appellate Body Report, Japan - Alcoholic Beverages II, 10; Appellate Body Report, US - Carbon Steel, [61]; Appellate Body Report, US - Softwood Lumber IV, [59]; Panel Report, Chile - Price Band System, [7.76]; Panel Report, US - Gambling, [6.9]; Panel Report, China Auto Parts, [7.165]; Panel Report, China - Intellectual Property Rights, [7.249], n 244. See also Michael Lennard, 'Navigating by the Stars: Interpreting the WTO Agreements' (2002) 5(1) Journal of International Economic Law 17, 18-19; WTO Dispute Settlement Body, Minutes of Meeting Held in the Centre William Rappard 25 September 1997, WT/DSB/M/37 (4 November 1997) 15 (statement by the EC); WTO Dispute Settlement Body, Minutes of Meeting Held in the Centre William Rappard on 16 January 1998, WT/DSB/M/40 (18 February 1998) 3, 8 (statement by India); WTO Dispute Settlement Body, Minutes of Meeting Held in the Centre William Rappard on 23 May 1997, WT/DSB/M/33 (25 June 1997) 10 (statement by the USA); WTO Dispute Settlement Body, Minutes of Meeting Held in the Centre William Rappard on 23 October 2002, WT/DSB/M/134 (29 January 2003) [48] (statement by Mexico).

128 LT/UR/A-2/DS/U/1 (signed 15 April 1994, entered into force 1 January 1995).

129 See, eg, Joost Pauwelyn, Conflict of Norms in Public International Law: How WTO Law Relates to Other Rules of International Law (Cambridge: Cambridge University Press, 2003) 305; Joel
} 
with most if not all of the VCLT. ${ }^{130}$ Accordingly, leading commentators such as Martti Koskenniemi and Joost Pauwelyn have concluded that Article 41 applies to the WTO agreements, ${ }^{131}$ and the Panel in Turkey - Textiles relied on Article 41(1)(b)(i) in reaching a conclusion on a customs union. ${ }^{132}$

Moreover, a number of other WTO dispute settlement decisions have applied provisions of the VCLT apart from Articles 31 to 33. For example, Arbitrators in proceedings under Article 22.6 of the DSU have relied on Articles 30, 60 and 70 of the VCLT. ${ }^{133}$ The Appellate Body in Brazil - Desiccated Coconut and Canada Patent Term and the Panel in EC - Sardines referred to Article 28 of the VCLT on 'Non-retroactivity of treaties' as a 'general principle of international law' and applied it on that basis. ${ }^{134}$ The Appellate Body has also recognised the 'principle of good faith' reflected in Article 26 of the VCLT. ${ }^{135}$ Similarly, the Panel in Korea Government Procurement described Article 26 of the VCLT as expressing the 'principle of pacta sunt servanda', falling with the 'general principles of customary international law'. ${ }^{136}$ The same Panel applied Article 48 of the VCLT (on error in a treaty) on the basis that it represented customary international law. ${ }^{137}$

The language used by Panels and the Appellate Body regarding various VCLT provisions has not always been consistent, but whether these provisions reflect 'general principles of law' within the meaning of Article 38(1)(c) of the Statute of the International Court of Justice, or rules or principles of 'customary international law' pursuant to Article 38(1)(b) of that Statute, Panels and the Appellate Body have been ready to apply them. Although the Appellate Body in EC - Sardines relied on the 'interpretation principle codified in Article 28 of the VCLT', ${ }^{138}$ it arguably applied Article 28 rather than merely using it as an interpretative rule.

The Panel in Korea - Procurement went even further than other WTO dispute settlement reports, stating that the relationship between the WTO agreements and

\footnotetext{
Trachtman, 'Review of Joost Pauwelyn, Conflict of Norms in Public International Law: How WTO Law Relates to Other Rules of International Law' (2004) 98 American Journal of International Law 855, 859.

130 See, eg, Gabčikovo-Nagymaros Project (Hungary v Slovakia) (Merits) [1997] ICJ Rep 7, [46], [99]; Anthony Aust, 'Vienna Convention on the Law of Treaties (1969)' in Rüdiger Wolfrum (ed), Max Planck Encyclopedia of Public International Law online edition at <www.mpepil.com>, last visited 28 August 2009, [15]-[16]; Ian Sinclair, The Vienna Convention on the Law of Treaties (Manchester: Manchester University Press, $2^{\text {nd }}$ ed, 1984) 14.

131 See, eg, Joost Pauwelyn, Conflict of Norms in Public International Law: How WTO Law Relates to Other Rules of International Law (Cambridge: Cambridge University Press, 2003) 475; International Law Commission, Fragmentation of International Law: Difficulties Arising from the Diversification and Expansion of International Law - Report of the Study Group - Finalized by Martti Koskenniemi, A/CN.4/L.682 (13 April 2006) [306].

132 Panel Report, Turkey - Textiles, [9.181]-[9.182].

133 Decision by the Arbitrators, EC-Hormones (US) (Article 22.6-EC), [51]; Decision by the Arbitrators, Brazil-Aircraft (Article 22.6-Brazil), [3.10].

134 Appellate Body Report, Brazil-Desiccated Coconut, 15; Appellate Body Report, CanadaPatent Term, [71]; Panel Report, EC-Sardines, [7.56]. See also Appellate Body Report, ECHormones, [128].

135 Appellate Body Report, US - Offset Act (Byrd Amendment), [296]-[297].

136 Panel Report, Korea-Procurement, [7.93].

137 Panel Report, Korea-Procurement, [7.123].

138 Appellate Body Report, EC-Sardines, [200].
} 
customary international law was broader than that expressed in Article 3.2 of the DSU. Specifically, '[c]ustomary international law ... applies to the extent that the WTO treaty agreements do not "contract out" from it'. ${ }^{139}$ This statement goes beyond what the Appellate Body has acknowledged with respect to the relationship between the WTO and public international law more generally. ${ }^{140}$ However, based on the evidence provided above, it is much less controversial to suggest that the VCLT's role in the WTO is not limited to guiding interpretation pursuant to Article 3.2 of the DSU. On this basis, I conclude that Article 41 does apply to the WTO agreements, except to the extent that specific WTO provisions indicate otherwise.

\section{(ii) Effect of Articles X and IX of the Marrakesh Agreement}

Joel Trachtman maintains that the WTO provisions on amendment and waiver (Articles X and IX of the Marrakesh Agreement Establishing the World Trade Organization ('Marrakesh Agreement') ${ }^{141}$ respectively) 'are best understood as contracting out of any possible permission for inter se modification' pursuant to the VCLT and that, in any case, they amount to a prohibition on inter se modifications pursuant to Article 41(1)(b). ${ }^{142}$

The WTO provisions on amendment and waiver do impose specific conditions on certain agreements that are essentially inter se modifications. For example, most amendments, if approved by consensus or the requisite majority of Members pursuant to Article X of the Marrakesh Agreement, would take effect only for those Members that have accepted them. ${ }^{143}$ These amendments are therefore inter se modifications of WTO rules between those Members that have accepted them. The Protocol Amending the TRIPS Agreement, if accepted by two-thirds of the WTO membership, would be an example of such an amendment, in accordance with Article X:3 of the Marrakesh Agreement. ${ }^{144}$ Similarly, the Ministerial Conference may decide by a three-fourths majority under Article IX:3 of the Marrakesh Agreement to waive an obligation imposed on a Member, effectively allowing that Member to modify the WTO rules as between itself and the rest of the WTO, without modifying the rules as between all WTO Members. For instance, in 2006, the General Council extended until 2012 the waiver of MFN and other WTO obligations with respect to measures taken by certain Members to prohibit the import or export of rough diamonds to non-Participants in the Kimberley Process Certification Scheme. ${ }^{145}$

\footnotetext{
139 Panel Report, Korea - Procurement, [7.96].

140 See generally Andrew Mitchell, Legal Principles in WTO Disputes (Cambridge: Cambridge University Press, 2008); Joost Pauwelyn, Conflict of Norms in Public International Law: How WTO Law Relates to Other Rules of International Law (Cambridge: Cambridge University Press, 2003); Tania Voon, Cultural Products in the World Trade Organization (Cambridge: Cambridge University Press, 2007) chapters 4-5.

141 LT/UR/A/2 (signed 15 April 1994, entered into force 1 January 1995).

142 Joel Trachtman, 'Review of Joost Pauwelyn, Conflict of Norms in Public International Law: How WTO Law Relates to Other Rules of International Law’ (2004) 98 American Journal of International Law 855, 858-859.

143 Marrakesh Agreement, Article X:1, X:3, X:5.

144 WTO General Council, Amendment of the TRIPS Agreement: Decision of 6 December 2005, WT/L/641 (8 December 2005) [3].

145 WTO General Council, Kimberley Process Certification Scheme for Rough Diamonds: Decision of 15 December 2006, WT/L/676 (19 December 2006) [1]-[2].
} 
To the extent that Articles X and IX of the Marrakesh Agreement allow for inter se modification, they may be seen as providing more detailed rules than Article 41 of the VCLT and therefore prevailing over it. However, Articles X and IX of the Marrakesh Agreement are not in fact specifically directed at inter se modifications, in the sense of groups of WTO Members seeking to modify the WTO agreements as between themselves. Rather, Article X is directed at proposals to amend the WTO agreements as a whole (for all Members), even though in some cases an amendment would apply only to those Members who had accepted it. Similarly, Article IX is directed at requests for waivers by individual Members, even though in some cases a number of Members may make a request at the same time and in relation to the same circumstances. These provisions do not clearly exclude the possibility of Article 41 of the VCLT playing a role in relation to other kinds of inter se modifications, and so may be properly regarded as falling within the terms of Article 41(a): they simply provide one means for WTO Members to achieve inter se modifications.

In determining the implications of Article 41 of the VCLT for inter se modifications not governed by Articles IX and $\mathrm{X}$ of the Marrakesh Agreement, the particular circumstances surrounding the modification in question must be examined. In the context of RTAs, inter se modifications are specifically contemplated in Article XXIV of the GATT 1994, as discussed further below. This confirms the conclusion that Articles IX and X of the Marrakesh Agreement do not 'cover the field' with respect to inter se modifications.

\section{(iii) Implications of Article 41(1) of the VCLT for RTAs}

Article XXIV of the GATT 1994 confirms that Members may enter RTAs modifying their WTO obligations, subject to the conditions laid out in that provision and the rest of the WTO agreements. Specifically, Article XXIV:5 states that 'the provisions of this Agreement shall not prevent, as between the territories of Members, the formation of a customs union or of a free-trade area or the adoption of an interim agreement necessary for the formation of a customs union or of a free-trade area', ${ }^{146}$ subject to certain conditions. ${ }^{147} \mathrm{~A}$ free-trade area or customs union will necessarily reduce the 'duties and other restrictive regulations of commerce' applicable between the parties, ${ }^{148}$ thereby prohibiting certain trade barriers that may be otherwise permitted under the WTO agreements, and so modifying the WTO agreements between RTA partners. Thus, Article XXIV at once provides an exception to the MFN rule (as between RTA partners and other WTO Members) and implicitly authorises inter se modifications (as between RTA partners).

Modifications in RTAs pursuant to Article XXIV may therefore fall within Article 41(1)(a) of the VCLT. This is apparently the conclusion reached by Koskenniemi for the International Law Commission's Study Group on Fragmentation, as well as Thomas Cottier and Marina Foltea, and James Mathis, ${ }^{149}$ with the result that the WTO

\footnotetext{
146 On interim agreements, see generally Lorand Bartels, “"Interim agreements” under Article XXIV

GATT’ (2009) 8(2) World Trade Review 339.

147 See below section IVB(ii).

148 GATT 1994, Article XXIV:8. See below section IVB(i).

149 International Law Commission, Fragmentation of International Law: Difficulties Arising from the Diversification and Expansion of International Law - Report of the Study Group - Finalized by Martti Koskenniemi, A/CN.4/L.682 (13 April 2006) [305]; Thomas Cottier and Marina Foltea, 'Constitutional
} 
rules alone govern modifications in RTAs, leaving no scope for Article 41(1)(b) of the VCLT with respect to RTAs. In contrast, Pauwelyn states that the WTO rules prohibit inter se agreements to liberalise trade among WTO Members unless they are extended on an MFN basis to all Members or they comply with the conditions in Article XXIV of the GATT 1994 (or the corresponding Article V of the General Agreement on Trade in Services ('GATS')). Pauwelyn's approach also appears to leave no room for Article 41(1)(b)(i) and (ii) of the VCLT with respect to RTAs, because he regards RTAs that do not comply with Article XXIV of the GATT 1994 as prohibited within the meaning of the 'chapeau' of Article 41(1)(b). ${ }^{150}$

However, RTAs are not necessarily entirely trade liberalising or trade restrictive (to use Pauwelyn's distinction), ${ }^{151}$ and many modifications to WTO rules that arise within RTAs are not expressly addressed in Article XXIV of the GATT 1994, or in other WTO provisions. In these circumstances, it is simplistic to suggest that the RTA as a whole either falls within Article 41(1)(a) or is prohibited under the chapeau of Article 41(1)(b). If a particular modification in an RTA is neither 'provided for' nor 'prohibited by' a treaty, the remaining conditions in Article 41(1)(b) become relevant. For instance, I have elsewhere argued that certain modifications in 'TRIPS-Plus' RTAs that limit flexibilities in relation to public health are contrary to Article 41(1)(b)(i) and (ii). ${ }^{152}$ Article XXIV of the GATT 1994 and the WTO's Agreement on Trade-Related Aspects of Intellectual Property Rights ('TRIPS Agreement') ${ }^{153}$ do not specify whether these kinds of modifications are allowed. Similarly, Article XXIV of the GATT 1994 and the DSU do not indicate explicitly whether WTO Members are entitled to modify dispute settlement procedures in RTAs, for example by including a choice of forum clause preventing resort to the WTO dispute settlement system in certain circumstances. This issue is likely to arise in a recent complaint brought by Mexico against the United States regarding tuna products, ${ }^{154}$ and Article 41(1)(b) of the VCLT may assist in resolving it.

Functions of the WTO and Regional Trade Agreements' in Lorand Bartels and Federico Ortino (eds), Regional Trade Agreements and the WTO Legal System (New York: Oxford University Press, 2006) 43, 55-56; James Mathis, Regional Trade Agreements in the GATT/WTO: Article XXIV and the Internal Trade Requirement (Cambridge University Press: Cambridge, 2002) 277-278.

150 Joost Pauwelyn, Conflict of Norms in Public International Law: How WTO Law Relates to Other Rules of International Law (Cambridge: Cambridge University Press, 2003) 317.

151 Joost Pauwelyn, Conflict of Norms in Public International Law: How WTO Law Relates to Other Rules of International Law (Cambridge: Cambridge University Press, 2003) 317-318.

${ }_{152}$ Andrew Mitchell and Tania Voon, 'Patents and Public Health in the WTO, FTAs and Beyond:

Tension and Conflict in International Law’ (2009) 43(3) Journal of World Trade 571, 596-598.

153 LT/UR/A-1C/IP/1 (signed 15 April 1994, entered into force 1 January 1995).

154 WTO, United States - Measures Concerning the Importation, Marketing and Sale of Tuna and

Tuna Products: Request for Consultations by Mexico, WT/DS381/1, G/L/858, G/TBT/D/32 (28 October 2008); WTO Dispute Settlement Body, Minutes of Meeting Held in the Centre William Rappard on 20 April 2009, WT/DSB/M/267 (26 June 2009) [77]. See also See Kyung Kwak and Gabrielle Marceau, 'Overlaps and Conflicts of Jurisdiction between the World Trade Organization and Regional Trade Agreements’ (2003) 41 Canadian Yearbook of International Law 83; Andrew Mitchell and Tania Voon, 'PTAs and Public International Law' in Simon Lester and Bryan Mercurio (eds), Bilateral and Regional Trade Agreements: Commentary and Analysis (Cambridge: Cambridge University Press, 2009) 114, 135-139; Joost Pauwelyn, 'Adding Sweeteners to Softwood Lumber: The WTO - NAFTA “Spaghetti Bowl” Is Cooking’ (2006) 9(1) Journal of International Economic Law 197; Joost Pauwelyn, Conflict of Norms in Public International Law: How WTO Law Relates to Other Rules of International Law (Cambridge: Cambridge University Press, 2003) 318. 
In order, then, to determine whether an RTA that restricts the application of trade remedies among RTA partners violates WTO law or public international law more generally, we must examine Article XXIV of the GATT 1994 in more detail. As we shall see, Article XXIV neither clearly provides for nor clearly prohibits such a modification, suggesting that the modification must meet the conditions of Article 41(1)(b)(i) of the VCLT (not affecting third party rights or obligations under the WTO agreements) and Article 41(1)(b)(ii) of the VCLT (not relating to a provision from which derogation is incompatible with the effective execution of the object and purpose of the WTO agreements as a whole). These conditions lend weight to the purpose of RTAs under Article XXIV, and to the importance of maximising intratrade liberalisation while minimising trade distortion and diversion with respect to WTO Members outside the RTA. Put differently, the VCLT Article 41(1)(b) conditions are reflected in Articles XXIV:4 and XXIV:8 of the GATT 1994, as discussed further below.

\section{B $\quad$ Compliance with GATT Article XXIV}

\section{(i) Article XXIV:8 - Lowering Intra-RTA Barriers}

Article XXIV:8 of the GATT 1994 defines a 'free-trade area' and a 'customs union', both of which fall within the scope of an 'RTA' for the purposes of this paper. ${ }^{155}$ These definitions make clear that RTAs are allowed under WTO rules because of their potential to act as stepping stones towards greater multilateral trade liberalisation. Accordingly, significant intra-RTA trade liberalisation is required to qualify as an RTA, and derogation from this requirement could well be 'incompatible with the effective execution of the object and purpose' of the WTO agreements as a whole. ${ }^{156}$ This reading is consistent with the purpose of the RTA exception as expressed in Article XXIV:4: 'The Members recognize the desirability of increasing freedom of trade by the development, through voluntary agreements, of closer integration between the economies of the countries parties to such agreements .... ${ }^{157}$

Article XXIV:8(b) defines a 'free-trade area' as:

A group of two or more customs territories in which the duties and other restrictive regulations of commerce (except, where necessary, those permitted under Articles XI, XII, XIII, XIV, XV and XX) are eliminated on substantially all the trade between the constituent territories in products originating in such territories.

Similarly, Article XXIV:8(a) defines a ‘customs union’ as the:

substitution of a single customs territory for two or more customs territories, so that:

(i) duties and other restrictive regulations of commerce (except, where necessary, those permitted under Articles XI, XII, XIII, XIV, XV and XX) are eliminated with respect to substantially all the trade between the constituent territories of the union or at least with respect to substantially all the trade in products originating in such territories ...

\footnotetext{
155 See above $\mathrm{n} 1$.

156 VCLT, Article 41(1)(b)(ii).

157 See also Understanding on the Interpretation of Article XXIV of the GATT 1994, preamble (as encompassed in paragraph 1(c)(iv) of the language incorporating the GATT 1994 into the Marrakesh Agreement). On the history of Article XXIV, see generally Kerry Chase, 'Multilateralism Compromised: The Mysterious Origins of GATT Article XXIV’ (2006) 5(1) World Trade Review 1.
} 
In addition, under Article XXIV:8(a)(ii), the members of a customs union must generally apply 'substantially the same duties and other regulations of commerce ... to the trade of territories not included in the union'. This second limb of the definition of a customs union may be relevant when members of a customs union apply trade remedies to non-union members but does not affect the central question of this paper, which concerns application by RTA partners of trade remedies among themselves.

Article XXIV:8 of the GATT 1994 has to date been inadequately illuminated in WTO dispute settlement proceedings and academic commentary. Greater certainty about the definition of 'free-trade areas' and 'customs unions' under this provision, specifically as regards the interaction between RTAs and trade remedies, could assist in encouraging existing RTA partners to amend their agreements and future RTA partners to abolish trade remedies amongst themselves. Below, I examine Article XXIV:8 in more detail in relation to the different forms of trade remedy that could be excluded in an RTA.

\section{(ii) Article XXIV:5 - Restricting Impact on Non-RTA Members}

An RTA that meets the definition of a 'free-trade area' or 'customs union in Article XXIV:8 of the GATT 1994 must also fulfil certain other conditions in order to benefit from the exemption in Article XXIV:5. These conditions demonstrate that RTAs must not on the whole lead to greater restrictions on external trade (that is, trade with nonRTA WTO Members); this would 'affect the enjoyment by the other parties of their rights under the treaty or the performance of their obligations' ${ }^{158}$ Again, this principle is reflected in Article XXIV:4, under which the Members 'recognize that the purpose of a customs union or of a free-trade area should be to facilitate trade between the constituent territories and not to raise barriers to the trade of other Members with such territories'. ${ }^{159}$ The Appellate Body has recognised Article XXIV:4 as setting forth 'the overriding and pervasive purpose for Article XXIV'. ${ }^{160}$

The Article XXIV:5 conditions include:

(a) with respect to a customs union, ... the duties and other regulations of commerce imposed at the institution of any such union ... in respect of trade with Members not parties to such union ... shall not on the whole be higher or more restrictive than the general incidence of the duties and regulations of commerce applicable in the constituent territories prior to the formation of such union ...;

(b) with respect to a free-trade area, ... the duties and other regulations of commerce maintained in each of the constituent territories and applicable at the formation of such free-trade area ... to the trade of Members not included in such area or not parties to such agreement shall not be higher or more restrictive than the corresponding duties and other regulations of commerce existing in the same constituent territories prior to the formation of the free-trade area ...

I have already discussed the implications of excluding RTA partners from antidumping and countervailing measures above, challenging assumptions that this will

\footnotetext{
158 VCLT, Article 41(1)(b)(i).

159 See also Understanding on the Interpretation of Article XXIV of the GATT 1994, preamble (as encompassed in paragraph 1(c)(iv) of the language incorporating the GATT 1994 into the Marrakesh Agreement).

160 Appellate Body Report, Turkey - Textiles, [57].
} 
necessarily increase the application of these measures to WTO Members not party to the relevant RTA or otherwise increase trade distortion. ${ }^{161}$ I further explore the meaning of Article XXIV:5 in the context of specific trade remedies below.

\section{(iii) Eliminating Safeguards}

In assessing the WTO-consistency of RTAs that exclude the application of global safeguards among their members, we must bear in mind the underlying purposes and detailed conditions of Article XXIV:8 and Article XXIV:5 of the GATT 1994. In addition, as noted above, unlike in the context of anti-dumping and countervailing measures, Article 2.2 of the Agreement on Safeguards stipulates that 'Safeguard measures shall be applied to a product being imported irrespective of its source'. In other words, safeguard measures must prima facie be applied on an MFN basis. ${ }^{162}$

Views on the exclusion of RTA partners from global safeguards generally take three forms: ${ }^{163}$ (i) RTA partners must impose global safeguards on each other's imports; ${ }^{164}$ (ii) RTA partners must not impose global safeguards on each other's imports; ${ }^{165}$ and (iii) RTA partners may impose global safeguards on each other's imports. ${ }^{166}$ The text of the WTO agreements does not clearly correspond to any of these approaches, which is why this is such a difficult issue. ${ }^{167}$ The Appellate Body has to date avoided resolving it in the abstract, ${ }^{168}$ addressing the parallelism requirement ${ }^{169}$ rather than GATT Article XXIV in disputes concerning the application of safeguards to RTA partners.

Beginning with the first approach, on its face, the language in parentheses in Article XXIV:8 suggests an exhaustive list, meaning that any measure that constitutes a duty or other restrictive regulation of commerce ('ORRC') and that is not mentioned in parentheses is included in the requirement to eliminate duties and ORRC on substantially all trade. ${ }^{170}$ As Article XIX is not mentioned in the parentheses in

161 See above sections IIIB(i), IIIB(ii).

162 See above n 46 and corresponding text.

163 On the three approaches, see generally WTO Committee on Regional Trade Agreements, Synopsis of 'Systemic Issues' Related to Regional Trade Agreements: Note by the Secretariat, WT/REG/W/37 (2 March 2000).

164 See, eg, Dukgeun Ahn, 'Foe or Friend of GATT Article XXIV: Diversity in Trade Remedy Rules' (2008) 11(1) Journal of International Economic Law 107.

165 See, eg, Angela Gobbi Estrella and Gary Horlick, ‘Mandatory Abolition of Anti-dumping, Countervailing Duties and Safeguards in Customs Unions and Free-Trade Areas Constituted Between World Trade Organization Members: Revisiting a Long-standing Discussion in Light of the Appellate Body’s Turkey-Textiles Ruling’ (2006) 40(5) Journal of World Trade 909.

166 See, eg, Mitsuo Matsushita, 'Legal Aspects of Free Trade Agreements: In the Context of Article XXIV of the GATT 1994’ in Mitsuo Matsushita and Dukgeun Ahn (eds), WTO and East Asia: New Perspectives (Cameron May: London, 2004) 497, 513-514; Petros Mavroidis, Patrick Messerlin and Jasper Wauters, The Law and Economics of Contingent Protection in the WTO (Edward Elgar: Cheltenham, 2008) 487-489.

167 See James Mathis, Regional Trade Agreements in the GATT/WTO: Article XXIV and the Internal Trade Requirement (Cambridge University Press: Cambridge, 2002) 174.

168 Appellate Body Report, Argentina - Footwear (EC), [110], [114]; Appellate Body Report, US Line Pipe, [198]-[199]; Appellate Body Report, US - Wheat Gluten, [99].

169 See above $\mathrm{n} 58$ and corresponding text.

170 Nicolas Lockhart and Andrew Mitchell, 'Regional Trade Agreements under GATT 1994: An

Exception and its Limits' in Andrew Mitchell (ed), Challenges and Prospects for the WTO (Cameron May: London, 2005) 217, 239. 
Article XXIV:8, and as safeguards under Article XIX take the form of increased duties or quantitative restrictions that may be described as ORRC, ${ }^{171}$ this means that RTA partners cannot be required to impose safeguards on each other's products. On the contrary, when taken as a whole together with all other duties and ORRC, safeguards should be eliminated on substantially all the relevant trade. Thus, the Panel in Argentina - Footwear (EC) stated: 'There is also no doubt in our minds that the letter and spirit of Article XXIV:8 of GATT permit member States of a customs union to agree on the elimination of the possibility to impose safeguard measures between the constituent territories'. ${ }^{172}$

How does this interpretation of Article XXIV:8 of the GATT 1994 (and the allowance under Article XXIV:5 for RTAs as defined in Article XXIV:8) sit with Article 2.2 of the Agreement on Safeguards? Any conflict between Article XXIV:5 of the GATT 1994 and Article 2.2 of the Agreement on Safeguards would ordinarily be resolved in favour of the latter, ${ }^{173}$ such that RTA partners would have to impose global safeguards on each other's imports. However, rather than viewing these provisions as conflicting, they should be interpreted harmoniously where possible, particularly given that these are both parts of the same treaty and that the Agreement on Safeguards constitutes an elaboration of GATT Article XIX. ${ }^{174}$ This is consistent with Footnote 1 of the Agreement on Safeguards, which specifically states that 'Nothing in this Agreement prejudges the interpretation of the relationship between Article XIX and paragraph 8 of Article XXIV of GATT 1994'. It is also consistent with the general rule of interpretation set out in Article 31(1) of the VCLT, which requires a treaty to be interpreted 'in good faith in accordance with the ordinary meaning to be given to the terms of the treaty in their context and in the light of its object and purpose'. ${ }^{175}$ On this reading, Article 2.2 need not override Article XXIV:5 and Article XXIV:8; read together, Article XXIV:5 of the GATT 1994 provides an exception to the MFN rule in Article 2.2 of the Agreement on Safeguards (with the words 'this Agreement' in Article XXIV:5 referring to the WTO treaty as a whole, rather than just the GATT 1994). ${ }^{176}$

171 Panel Report, US - Line Pipe, [7.141] (the Appellate Body declared these findings moot and of no legal effect: Appellate Body Report, US - Line Pipe, [199]); Nicolas Lockhart and Andrew Mitchell, 'Regional Trade Agreements under GATT 1994: An Exception and its Limits' in Andrew Mitchell (ed), Challenges and Prospects for the WTO (Cameron May: London, 2005) 217, 237-238; Angela Gobbi Estrella and Gary Horlick, 'Mandatory Abolition of Anti-dumping, Countervailing Duties and Safeguards in Customs Unions and Free-Trade Areas Constituted Between World Trade Organization Members: Revisiting a Long-standing Discussion in Light of the Appellate Body's Turkey-Textiles Ruling' (2006) 40(5) Journal of World Trade 909, 913-914; Dukgeun Ahn, 'Foe or Friend of GATT Article XXIV: Diversity in Trade Remedy Rules' (2008) 11(1) Journal of International Economic Law 107, 120.

172 Panel Report, Argentina - Footwear (EC), [8.99], see also [8.97] (the Appellate Body declared these findings moot and of no legal effect: Appellate Body Report, Argentina - Footwear (EC), [110]).

173 Marrakesh Agreement, General interpretative note to Annex $1 A$.

174 See Appellate Body Report, Argentina - Footwear (EC), [81].

175 See above n 128 and corresponding text.

176 Panel Report, US - Line Pipe, [7.146], [7.150], [7.158], [7.160], [7.163] (the Appellate Body declared these findings moot and of no legal effect: Appellate Body Report, US - Line Pipe, [199]); Joost Pauwelyn, 'The Puzzle of WTO Safeguards and Regional Trade Agreements' (2004) 7(1) Journal of International Economic Law 109, 128-130; Cf Alan Sykes, The WTO Agreement on Safeguards: A Commentary (Oxford University Press: Oxford, 2006) 234. 
The drafting history of Article XXIV (which may be referred to pursuant to Article 32 of the VCLT) confirms the inapplicability of the first approach, given that the debate about the relationship between Articles XIX and XXIV centred on the second two approaches, and whether RTA partners either 'need not' or 'should not' apply safeguards to each other's imports. ${ }^{177}$ The drafting history also indicates that Article XIX was deliberately omitted from the list of exceptions. ${ }^{178}$ Although Article XXI (security exceptions) is similarly omitted from the list of exceptions in parentheses, this omission is also arguably explained by the drafting history. ${ }^{179}$

Turning then to the second approach, requiring RTA partners to exempt each other from global safeguards may be consistent with the MFN rule in Article 2.2 of the Agreement on Safeguards. However, it is inconsistent with the language of Article XXIV:8. Even assuming that safeguards constitute ORRC and that the exceptions listed in parentheses in Article XXIV:8 comprise an exhaustive list (as suggested above), flexibility remains inherent in Article XXIV:8 because the obligation on RTA partners is simply to eliminate duties and ORRC on substantially all the relevant trade rather than on all the trade. The Panel in Argentina - Footwear (EC) and a number of commentators have reached a similar conclusion. ${ }^{180}$

The first two approaches also seem inconsistent with the purpose of RTAs as expressed in Article XXIV:4. If RTA partners must impose global safeguards on each other's imports, this is consistent with Article 2.2 and will reduce trade distortion and diversion in accordance with Article XXIV:5, but it will restrict intra-RTA trade contrary to the principle behind Article XXIV:8, defeating the purpose of allowing RTAs in the first place. At the same time, requiring RTA partners to impose global safeguards on each other may contravene Article 41(1)(b)(ii) of the VCLT, since it derogates from the purpose of the WTO agreements of promoting trade liberalisation as a means to improving global welfare. Conversely, if RTA partners must not impose global safeguards on each other's imports, this will have a positive impact on intraRTA trade liberalisation in accordance with Article XXIV:8 of the GATT 1994, but it will necessarily create trade distortion and diversion of trade away from WTO Members not party to the relevant RTA, contrary to the principle behind Article

\footnotetext{
177 WTO Committee on Regional Trade Agreements, Systemic Issues Related to Other Regulations of Commerce: Background Note by the Secretariat - Revision, WT/REG/W/17/Rev.1 (5 February 1998), [15] (referring to a September 1990 decision).

${ }_{178}$ WTO Committee on Regional Trade Agreements, Systemic Issues Related to Other Regulations of Commerce: Background Note by the Secretariat - Revision, WT/REG/W/17/Rev.1 (5 February 1998), n 9 (referring to a Secretariat Note of 10 August 1988).

179 Angela Gobbi Estrella and Gary Horlick, 'Mandatory Abolition of Anti-dumping, Countervailing Duties and Safeguards in Customs Unions and Free-Trade Areas Constituted Between World Trade Organization Members: Revisiting a Long-standing Discussion in Light of the Appellate Body's Turkey-Textiles Ruling' (2006) 40(5) Journal of World Trade 909, 940-941. See also, contra, Petros Mavroidis, 'If I Don't Do It, Somebody Else Will (Or Won’t): Testing the Compliance of Preferential Trade Agreements with the Multilateral Rules’ (2006) 40(1) Journal of World Trade Law 187, 201. 180 Panel Report, Argentina - Footwear (EC), [8.97], [8.101] (Appellate Body declared these findings moot and of no legal effect: Appellate Body Report, Argentina - Footwear (EC), [110]); Dukgeun Ahn, 'Foe or Friend of GATT Article XXIV: Diversity in Trade Remedy Rules' (2008) 11(1) Journal of International Economic Law 107, 121; Joost Pauwelyn, 'The Puzzle of WTO Safeguards and Regional Trade Agreements’ (2004) 7(1) Journal of International Economic Law 109, 127; Alan Sykes, The WTO Agreement on Safeguards: A Commentary (Oxford University Press: Oxford, 2006) 233-234.
} 
XXIV:5 of the GATT 1994, Article 2.2 of the Agreement on Safeguards, and Article 41(1)(b)(i) of the VCLT.

The third approach, in contrast, leaves flexibility to RTA partners and charges them with the responsibility of ensuring compliance with the letter and spirit of the WTO rules. In particular, in accordance with GATT Article XXIV:5 and VCLT Article 41(1)(b)(i), RTA partners need to minimise the impact on other WTO Members of excluding each other from global safeguards, should they choose to do so. At the same time, pursuant to GATT Article XXIV:8 and VCLT Article 41(1)(b)(ii), RTA partners need to ensure sufficient intra-RTA trade liberalisation should they decide to impose global safeguards on each other.

This approach does not necessarily render the list of exceptions in Article XXIV:8 redundant, as argued by Estrella and Horlick. ${ }^{181}$ Rather, provisions falling within that list may be maintained as long as they are 'necessary' (as stated in Article XXIV:8), whereas duties and other ORRC not falling within that list must be eliminated on substantially all the trade. It is true that this means that the WTO-consistency of the RTA could vary from time to time, ${ }^{182}$ but that is the case with respect to any RTA anyway. Assessing consistency with Article XXIV:8 is a difficult task requiring substantial evidence and fact collection because 'the entire gamut of duties and other regulations of commerce must be examined', ${ }^{183}$ and 'the examination of individual measures, regulations, products covered and trade flows affected may be required'. ${ }^{184}$ Under this third approach, safeguards are assessed along with all the other remaining restrictive trade measures, given that maintaining either will have similar trade effects. ${ }^{185}$ The Appellate Body's decision in Turkey - Textiles also does not preclude this third approach. As explained elsewhere, the Appellate Body's 'timing' and 'necessity' requirements should be read as applying (if at all) ${ }^{186}$ only to Article XXIV:5 (external trade) and not to Article XXIV:8 (internal trade). ${ }^{187}$

181 Angela Gobbi Estrella and Gary Horlick, 'Mandatory Abolition of Anti-dumping, Countervailing Duties and Safeguards in Customs Unions and Free-Trade Areas Constituted Between World Trade Organization Members: Revisiting a Long-standing Discussion in Light of the Appellate Body's Turkey-Textiles Ruling' (2006) 40(5) Journal of World Trade 909, 932.

182 See Nicolas Lockhart and Andrew Mitchell, 'Regional Trade Agreements under GATT 1994: An Exception and its Limits’ in Andrew Mitchell (ed), Challenges and Prospects for the WTO (Cameron May: London, 2005) 217, 239; James Mathis, 'Regional Trade Agreements and Domestic Regulation: What Reach for “Other Restrictive Regulations of Commerce”?' in Lorand Bartels and Federico Ortino (eds), Regional Trade Agreements and the WTO Legal System (Oxford University Press: Oxford, 2006) $79,89$.

183 Joost Pauwelyn, 'Comment: Nothing dramatic (... regarding administration of customs laws)' (2009) 8(1) World Trade Review 45, 47, referring to Appellate Body Report, Turkey - Textiles. See also WTO Committee on Regional Trade Agreements, Systemic Issues Related to Other Regulations of Commerce: Background Note by the Secretariat - Revision, WT/REG/W/17/Rev.1 (5 February 1998), [17].

184 Understanding on the Interpretation of Article XXIV of the GATT 1994, [2].

185 See Alan Sykes, The WTO Agreement on Safeguards: A Commentary (Oxford University Press: Oxford, 2006) 232.

186 See the critique in Joost Pauwelyn, 'The Puzzle of WTO Safeguards and Regional Trade Agreements’ (2004) 7(1) Journal of International Economic Law 109, 132-135.

187 Panel Report, US - Line Pipe, [7.148], n 137 (the Appellate Body declared these findings moot and of no legal effect: Appellate Body Report, US - Line Pipe, [199]); Nicolas Lockhart and Andrew Mitchell, 'Regional Trade Agreements under GATT 1994: An Exception and its Limits' in Andrew Mitchell (ed), Challenges and Prospects for the WTO (Cameron May: London, 2005) 217, 226-228; Cf 
My assessment of the three approaches with respect to the purpose of RTAs is summarised in the table below.

\begin{tabular}{|c|c|c|c|}
\hline \multirow{2}{*}{ Negative trade impact } & \multicolumn{3}{|c|}{ Approach to global safeguards among RTA parties } \\
\cline { 2 - 4 } & Must impose & Must not impose & May impose \\
\hline $\begin{array}{c}\text { External: trade distortion } \\
\text { and diversion away from } \\
\text { non-RTA WTO Members }\end{array}$ & Low & High & $\begin{array}{c}\text { Low } \\
\text { (RTA parties to ensure } \\
\text { compliance with } \\
\text { GATT Art XXIV:5 and } \\
\text { VCLT Art 41(1)(b)(i)) }\end{array}$ \\
\hline $\begin{array}{c}\text { Internal: trade restrictions } \\
\text { on RTA parties }\end{array}$ & High & Low & $\begin{array}{c}\text { Low } \\
\text { (RTA parties to ensure } \\
\text { compliance with } \\
\text { GATT Art XXIV:8 and } \\
\text { VCLT Art 41(1)(b)(ii)) }\end{array}$ \\
\hline
\end{tabular}

\section{(iv) Eliminating Anti-Dumping and Countervailing Measures}

Like Article XIX, Article VI of the GATT 1994 is not included in the list of exceptions in Article XXIV:8. However, as anti-dumping and countervailing measures are not imposed on an MFN basis, ${ }^{188}$ many of the difficulties associated with analysing safeguards in RTAs do not arise. In particular, the potential conflict between the MFN provision in Article 2.2 of the Agreement on Safeguards and the exception in GATT Article XXIV disappears in the context of anti-dumping and countervailing measures. Nevertheless, agreeing not to impose anti-dumping or countervailing measures on RTA partners would probably violate the general MFN rule in GATT Article I:1, and so such an RTA would still need to rely on the exception in Article XXIV.

In interpreting the meaning of Article XXIV for such an RTA, the option of requiring RTA partners to actually impose anti-dumping and countervailing measures on each other makes little sense, since all WTO Members are free not to impose any such measures or not to impose them on imports from particular countries. This leaves the options of requiring RTA partners to eliminate anti-dumping and countervailing measures, or permitting RTA partners to apply these measures. In 1994, Gabrielle Marceau called for the elimination of anti-dumping duties within free-trade areas. ${ }^{189}$

A free-trade area where anti-dumping duties are phased out appears to be the minimum level integration necessary for a successful trade deal. ... This crucial legal step, phasing out of internal anti-dumping duties, will further integration and push free-trade areas closer to customs union. This would explain why free-trade areas, imperfect customs unions, were accepted: they can effectively lead to further integration. Regional and multilateral trade can therefore be reconciled with GATT.

Alan Sykes, The WTO Agreement on Safeguards: A Commentary (Oxford University Press: Oxford, 2006) 235-236.

188 See above sections IIIB(i) and IIIB(ii).

189 Gabrielle Marceau, Anti-Dumping and Anti-Trust Issues in Free-trade Areas (Oxford University Press: Oxford, 1994) 187-192. See also Michael Hart, 'Introduction’ in Michael Hart (ed), Finding Middle Ground: Reforming the Antidumping Laws in North America (Ottawa, Centre for Trade Policy and Law, 1997) 1, 15. 
The benefits of excluding RTA partners from anti-dumping and countervailing measures are clear, given their doubtful economic foundations. ${ }^{190}$ However, keeping in mind the potential problem of such exclusion leading to greater imposition of antidumping and countervailing measures on other WTO Members, ${ }^{191}$ and the flexibility inherent in Article XXIV:8, ${ }^{192}$ I conclude that RTA partners have the same obligations with respect to anti-dumping and countervailing measures as they do with respect to safeguards: namely, they are entitled to impose them on each other provided that they ensure compliance with Article XXIV:5 and XXIV:8 of the GATT 1994, and Article 41(1)(b) of the VCLT.

One possible contrary argument is that anti-dumping and countervailing measures are not ORRCs at all, and therefore RTA partners have no obligation to reduce them pursuant to Article XXIV:8. This argument is premised on the assumption that antidumping and countervailing measures are designed to offset unfair trading practices of other Members (in the form of dumping or subsidisation) and thus do not represent restrictive measures of the imposing Member. However, even accepting this assumption, it does not explain why provisions such as GATT Article XX (General Exceptions) are included in the Article XXIV:8 list, when measures falling under Article XX are also aimed at specific legitimate purposes and therefore justified derogations from other WTO provisions. If exceptions to WTO rules were not intended to fall within the description of ORRCs, the drafters need not have included GATT Article XX in the list of provisions in Article XXIV:8.

\section{Compliance with the Enabling Clause}

Paragraph 2(c) of the Enabling Clause applies the exemption from MFN treatment in paragraph 1 to:

Regional or global arrangements entered into amongst developing country Members for the mutual reduction or elimination of tariffs and, in accordance with criteria or conditions which may be prescribed by the Ministerial Conference, for the mutual reduction or elimination of non-tariff measures, on products imported from one another ...

This provision may be seen as equivalent to GATT Article XXIV in the context of RTAs among developing country Members. Additional conditions on these RTAs are found in paragraph 3 of the Enabling Clause, which provides that 'differential and more favourable treatment' provided under the Enabling Clause:

(a) shall be designed to facilitate and promote the trade of developing countries and not to raise barriers to or create undue difficulties for the trade of any other contracting parties;

(b) shall not constitute an impediment to the reduction or elimination of tariffs and other restrictions to trade on a most-favoured-nation basis ...

These conditions reflect concerns similar to those encompassed in Article XXIV:5 and XXIV:8 of the GATT $1994^{193}$ and Article 41(1)(b) of the VCLT, and the above

\footnotetext{
190 See above section IIB(i).

191 See above sections IIIB(i) and IIIB(ii).

192 See above $n 180$ and corresponding text.

193 Cf David Gantz, Regional Trade Agreements: Law, Policy and Practice (Durham, North Carolina: Carolina Academic Press, 2009) 43.
} 
analysis in relation to the three types of trade remedies apply equally to RTAs among developing country Members. Requiring these RTA partners to impose safeguards against each other would be contrary to the purpose of promoting the trade of developing countries as set out in paragraph 3(a) of the Enabling Clause, and requiring them to impose anti-dumping or countervailing measures is contrary to the non-MFN basis on which they are imposed in any case. Requiring them to eliminate trade remedies against each other could raise barriers to non-RTA partners, particularly through trade diversion arising from global safeguards applied on a discriminatory basis, contrary to paragraph 3(a) and 3(b). An approach that grants RTA partners flexibility in choosing whether to impose particular trade remedies against each other properly places the onus on the relevant Members to maintain compliance with the Enabling Clause.

\section{CONCLUSION}

This paper aims to contribute towards a reduction in the use of trade remedies among WTO Members for the benefit of all WTO Members and the global economy as a whole. It does so by taking advantage of the multiplicity of RTAs and their capacity to influence trade-related conduct and beliefs. This issue deserves further scholarly attention, especially from a legal and economic perspective and drawing on the wealth of raw material available in the context of RTAs.

A few existing RTAs as identified in this paper demonstrate that some WTO Members may be willing to restrict various forms of trade remedies amongst themselves, and that this is a feasible and realistic approach, even in the absence of deep integration between the RTA parties. The above analysis of WTO rules concerning trade remedies in RTAs shows that RTA partners are permitted to exclude the application of anti-dumping, countervailing and safeguard measures among themselves, provided that they continue to limit negative trade impacts on non-RTA WTO Members in accordance with Article XXIV:5 of the GATT 1994, Article 41(1)(b)(i) of the VCLT, and paragraph 3(a) and 3(b) of the Enabling Clause. Doing so will further the underlying objectives of allowing RTAs in the WTO and increase intra-RTA trade liberalisation in accordance with GATT Article XXIV:8, VCLT Article 41(1)(b)(ii), and Enabling Clause paragraph 3(a). This reading should assist in increasing certainty about the interaction between RTAs and trade remedies with the goal of encouraging existing RTA parties to amend their agreements and future RTA parties to abolish or at least restrict trade remedies among themselves. This would be one step towards limiting trade remedies among WTO Members and, ultimately, replacing anti-dumping measures with competition disciplines, countervailing measures with WTO dispute settlement, and safeguards with a reformed regime. 


\section{ANNEX 1: WTO-EQUIVALENT RTAS}

This Annex categorises 118 RTAs that do not change WTO trade remedy rules or make only minor modifications to those rules.

The following Category 1 RTAs do not mention WTO trade remedies or make no significant change to the relevant WTO provisions:

1. Agreement on Foundation of Eurasian Economic Community (Belarus, Kazakhstan, Kyrgyz Republic, Russian Federation, Tajikistan)

2. Armenia - Kazakhstan

3. Armenia - Moldova

4. Armenia - Russian Federation

5. Armenia - Turkmenistan

6. Armenia - Ukraine

7. Australia - Chile

8. Commonwealth of Independent States (Armenia, Azerbaijan, Belarus, Georgia, Kazakhstan, Kyrgyz Republic, Moldova, Russian Federation, Tajikistan, Turkmenistan, Ukraine, Uzbekistan; not yet ratified by all parties)

9. EC - Egypt

10. Faroe Islands - Switzerland

11. Georgia - Armenia

12. Georgia - Azerbaijan

13. Georgia - Kazakhstan

14. Georgia - Russian Federation

15. Georgia - Turkmenistan
16. Georgia - Ukraine

17. Kyrgyz Republic - Armenia

18. Kyrgyz Republic - Kazakhstan

19. Kyrgyz Republic - Moldova

20. Kyrgyz Republic - Russian Federation

21. Kyrgyz Republic - Ukraine

22. Kyrgyz Republic - Uzbekistan

23. Melanesian Spearhead Group Trade Agreement (Papua New Guinea, Solomon Islands, Vanuatu)

24. Southern African Development Community (Botswana, Lesotho, Madagascar, Malawi, Mauritius, Mozambique, Namibia, South Africa, Swaziland, Tanzania, Zambia, Zimbabwe; Angola and the Democratic Republic of Congo still to join)

25. The Unified Economic Agreement Between the Countries of the Gulf Cooperation Council (Bahrain, Kuwait, Oman, Qatar, Saudi Arabia, United Arab Emirates)

The following Category 2 RTAs allow for the imposition of bilateral safeguards without otherwise changing WTO trade remedy rules:

1. Albania - Bosnia Herzegovina

2. Albania - Bulgaria

3. Albania - FYROM

4. Albania - Moldova

5. Albania - Serbia \& Montenegro

6. Asia-Pacific Trade Agreement (Bangladesh, China, India, Laos, Republic of Korea, Sri Lanka)

7. Association of Southeast Asian Nations ('ASEAN': Brunei Darussalam, Cambodia, Indonesia, Laos, Malaysia, Myanmar, Philippines, Singapore, Thailand, Vietnam) - China

8. ASEAN - Republic of Korea

9. Bulgaria - Bosnia Herzegovina

10. Chile - China

11. Chile - India

12. Chile - Japan
13. Chile - Republic of Korea

14. China - Pakistan

15. Croatia - Albania

16. EC - Mexico

17. EC - South Africa

18. EC - Turkey Customs Union

19. India - Afghanistan

20. India - MERCOSUR

21. India - Sri Lanka

22. Japan - ASEAN

23. Japan - Malaysia

24. Japan-Mexico

25. Trans-Pacific Strategic Economic Partnership Agreement (Brunei Darussalam, Chile, NZ, Singapore)

26. US - Chile

27. US - Morocco

28. US - Oman 
The following Category 3 RTAs make procedural changes to the application of trade remedies under WTO rules and provide additional rules for the application of bilateral safeguards:
1. Albania - Kosovo
2. Albania - Romania
3. ASEAN
4. Bulgaria - Former Yugoslav Republic of Macedonia ('FYROM')
5. Bulgaria - Israel
6. Bulgaria - Serbia \& Montenegro
7. Canada - Costa Rica (Bulgaria, Croatia, Czech Republic, Hungary, Poland, Romania, Slovak Republic)
8. Central European Free Trade Agreement
9. Chile - Costa Rica
10. Chile - El Salvador
11. Croatia - Bosnia Herzegovina
12. Croatia-FYROM
13. Croatia - Serbia \& Montenegro
14. East African Community (Kenya, Uganda, Tanzania)
15. EC - Algeria
16. EC - Bulgaria
17. EC-FYROM
18. EC - Iceland
19. EC - Israel
20. EC - Jordan
21. EC - Lebanon
22. EC - Morocco
23. EC - Norway
24. EC - Palestine Liberation Organization ('PLO')
25. EC - Romania
26. EC - Syria
27. EC - Switzerland and Liechtenstein
28. EC - Tunisia
29. Economic Cooperation Organisation Trade Agreement (Afghanistan, Azerbaijan, Iran, Kazakhstan, Kyrgyz Republic, Pakistan, Tajikistan, Turkey, Turkmenistan, Uzbekistan)

30. European Free Trade Association ('EFTA') - Bulgaria

31. EFTA - Canada

32. EFTA - Croatia

33. EFTA - Israel

34. EFTA - Jordan

35. EFTA - Lebanon

36. EFTA - Macedonia

37. EFTA - Mexico

38. EFTA - Morocco

39. EFTA - Palestinian Authority

40. EFTA - Romania

41. EFTA - Tunisia

42. EFTA - Turkey

43. Faroe Islands - Iceland

44. Faroe Islands - Norway

45. FYROM - Bosnia Herzegovina

46. Israel - Turkey

47. Japan - Singapore

48. Moldova - Bosnia Herzegovina

49. Moldova - Bulgaria

50. Moldova - Croatia

51. Moldova-FYROM

52. Moldova - Serbia \& Montenegro

53. Romania - Bosnia Herzegovina

54. Romania-FYROM

55. Romania - Israel

56. Romania - Moldova

57. Romania - Serbia \& Montenegro

58. Romania - Turkey

59. South Asian Free Trade Area (Bangladesh, Bhutan, India, Maldives, Nepal, Pakistan, Sri Lanka)

60. Turkey - Bosnia Herzegovina

61. Turkey - Bulgaria

62. Turkey - Croatia

63. Turkey - FYROM

64. Turkey - Morocco

65. Turkey - PLO

66. Turkey - Tunisia 


\section{ANNEX 2: WTO-PLUS RTAS}

The following RTAs restrict the application of these trade remedies between RTA partners:

\begin{tabular}{|c|c|c|}
\hline Anti-dumping measures $\#$ & $\begin{array}{c}\text { Countervailing } \\
\text { measures }\end{array}$ & Global safeguards \\
\hline $\begin{array}{ll}\text { 1. } & \text { ANZ Protocol } \\
\text { 2. } & \text { Canada - Chile } \\
\text { 3. } & \text { China - Hong Kong } \\
\text { 4. } & \text { China - Macau } \\
\text { 5. } & \text { EC } \\
\text { 6. } & \text { EFTA } \\
\text { 7. } & \text { EFTA - Chile } \\
\text { 8. } & \text { EFTA - Singapore }\end{array}$ & $\begin{array}{ll}\text { 1. } & \text { China - Hong Kong } \\
\text { 2. China - Macau } \\
\text { 3. EC } \\
\text { 4. } \\
\text { EFTA }\end{array}$ & $\begin{array}{l}\text { 1. Andean Community } \\
\text { (Bolivia, Colombia, } \\
\text { Ecuador, Peru) } \\
\text { 2. ANZ Protocol* } \\
\text { 3. Australia - Thailand } \\
\text { 4. Canada - Chile } \\
\text { 5. Canada - Colombia } \\
\text { 6. Canada - Israel } \\
\text { 7. EC - Chile Interim } \\
\text { Agreement } \\
\text { 8. EC* } \\
\text { 9. Israel - Mexico } \\
\text { 10. MERCOSUR* } \\
\text { 11. NAFTA } \\
\text { 12. NZ - China } \\
\text { 13. NZ - Singapore* } \\
\text { 14. NZ - Thailand } \\
\text { 15. Panama - Costa Rica } \\
\text { 16. Panama - El Salvador } \\
\text { 17. Panama - Taiwan } \\
\text { 18. Singapore - Australia* } \\
\text { 19. Singapore - India } \\
\text { 20. Singapore - Jordan } \\
\text { 21. Singapore - Panama } \\
\text { 22. US - Australia } \\
\text { 23. US - Central America } \\
\text { and Dominican } \\
\text { Republic } \\
\text { 24. US - Colombia } \\
\text { 25. US - Israel } \\
\text { 26. US - Jordan } \\
\text { 27. US - Panama } \\
\text { 28. US - Peru } \\
\text { 29. US - Republic of } \\
\text { Korea } \\
\text { 30. US - Singapore }\end{array}$ \\
\hline
\end{tabular}

${ }^{\#}$ Anti-dumping and countervailing measures are also excluded under the EEA in most sectors. See above nn 86, 100.

*These RTAs preclude both global and bilateral safeguards between the RTA partners. 